University of Nebraska - Lincoln

DigitalCommons@University of Nebraska - Lincoln

Historical Perspective and Contribution of US Researchers into the Field of Self-Propagating High-Temperature Synthesis (SHS)/Combustion Synthesis (CS): Personal Reflections

J. W. McCauley

Army Research Laboratory, Aberdeen Proving Grounds, MD, USA

J. A. Puszynski

South Dakota School of Mines and Technology, 501 East Saint Joseph Street, Rapid City, SD, 57701 USA

Follow this and additional works at: https://digitalcommons.unl.edu/usarmyresearch

Part of the Operations Research, Systems Engineering and Industrial Engineering Commons

McCauley, J. W. and Puszynski, J. A., "Historical Perspective and Contribution of US Researchers into the Field of Self-Propagating High-Temperature Synthesis (SHS)/Combustion Synthesis (CS): Personal Reflections" (2008). US Army Research. 38.

https://digitalcommons.unl.edu/usarmyresearch/38

This Article is brought to you for free and open access by the U.S. Department of Defense at DigitalCommons@University of Nebraska - Lincoln. It has been accepted for inclusion in US Army Research by an authorized administrator of DigitalCommons@University of Nebraska - Lincoln. 


\title{
Historical Perspective and Contribution of US Researchers into the Field of Self-Propagating High-Temperature Synthesis (SHS)/Combustion Synthesis (CS): Personal Reflections*
}

\author{
J. W. McCauley ${ }^{a}$ and J. A. Puszynski ${ }^{b}$ \\ ${ }^{a}$ Army Research Laboratory, Aberdeen Proving Grounds, MD, USA \\ ${ }^{b}$ South Dakota School of Mines and Technology, 501 East Saint Joseph Street, Rapid City, SD, 57701 USA \\ e-mail: Jan.Puszynski@sdsmt.edu \\ Received October 26, 2007
}

PACS numbers: 81.05.Je, 81.20.Ka

DOI: $10.3103 / \mathrm{S} 106138620801007 \mathrm{X}$

\section{INTRODUCTION}

In 1967, Merzhanov, Skhiro, and Borovinskaya published the first comprehensive paper describing self-sustaining character of reactions in a condensed phase, which could be utilized for synthesis of many ceramic and intermetallic materials [1]. In this paper, the authors demonstrated the principle of the so called "solid flame" using reactions between transition metals and boron, carbon or nitrogen. The world-wide combustion synthesis community considers this comprehensive paper and subsequent integrated experimental and theoretical research effort conducted in the former Soviet Union as the beginning of a new approach and method of synthesizing advanced high temperature materials. The main research was conducted by many Russian scientists at the Branch of Russian Academy of Sciences in Chernogolovka under the leadership of Professors Merzhanov and Borovinskaya [2-11].

During that period of our history, free exchange of information among scientists from different countries was very limited due to the cold war. The main source of information on research discoveries and accomplishments of Russian scientists available to US and other researchers was through publications in Russian journals or their translated versions. Such as Combustion, Explosion, and Shock Waves, Doklady Academy Nauk SSSR, Soviet Powder Metallurgy of Metals and Ceramics, Inorganic Materials, and Doklady Physical Chemistry were the most searched journals in the area of combustion synthesis. In the early 90s, a new International Journal of Self-Propagating High-Temperature

\footnotetext{
* Presented at the International Conference on Historical Aspects of SHS in Different Countries, October 22-27, 2007, Chernogolovka, Moscow, Russia.
}

Synthesis was created and it is published quarterly since its inception.

Self-propagating high-temperature synthesis (SHS) also called combustion synthesis (CS) is the exothermic process in which the reaction between two or more solid reactants or gas and condensed reactants takes place in a self-sustaining regime leading to the formation of solid products of a higher value [12-14]. During the past forty years, hundreds of different compounds, including, nitrides, borides, carbides, silicides, sulfides, phosphides, hydrides, and oxides of many elements as well as intermetallics, composites, nonstoichiometric compounds, and solid solutions were successfully synthesized by this method [12-18]. Some materials have been successfully scaled-up and produced by the industry. To this group of materials among others belong: carbides of titanium, zirconium, tungsten, tantalum, boron and silicon, titanium diboride, molybdenum disilicide, aluminum nitride, silicon nitride, nickel aluminides, titanium nickelide, zirconium aluminides, and a number of composites (e.g. $\mathrm{TiC}-\mathrm{TiB}_{2}$ and $\mathrm{SiC}-\mathrm{Si}_{3} \mathrm{~N}_{4}$ ) or solid solutions such as SIALONs and aluminum oxynitride (ALON).

\section{REVIEW OF EARLY RESEARCH IN USA AND WESTERN COUNTRIES}

A historical perspective on research in the area of exothermic reactions occurring in a self-sustaining regime was well documented by Hlavacek [19] and McCauley [16]. In the United States, the first reported research utilizing self-sustaining character of condensed-phase reactions was conducted by Walton and Poulos [20] in the mid and late 1950s. These authors explored thermite reactions to make refractory coatings. Mixtures of aluminum and/or magnesium with 


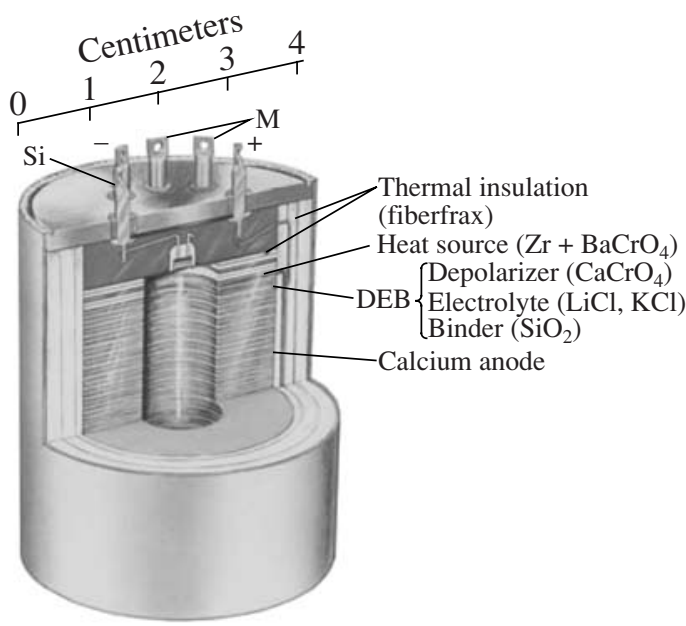

$$
\begin{aligned}
& \text { - } \mathrm{Zr}+(\text { Air }) \rightarrow \mathrm{ZrO}_{2} \\
& \text { - } \mathrm{Zr}+\mathrm{BaCrO}_{4}+(\text { Air }) \\
& \text { - } 3 \mathrm{Zr}+4 \mathrm{BaCrO}_{4} \rightarrow 3 \mathrm{ZrO}_{2}+4 \mathrm{BaO}+\mathrm{Cr}_{2} \mathrm{O}_{3} \\
& 3 \mathrm{ZrO}_{2}+3 \mathrm{BaO} \rightarrow 3 \mathrm{BaZrO}_{3} \\
& \text { - } 3 \mathrm{Zr}+2 \mathrm{BaCrO}_{4} \rightarrow 3 \mathrm{ZrO}_{2}+2 \mathrm{BaO}+2 \mathrm{Cr} \\
& 3 \mathrm{ZrO}_{2}+2 \mathrm{BaO} \rightarrow 2 \mathrm{BaZrO}_{3} \\
& 15-50 \mathrm{wt} \% \mathrm{Zr} \quad 273-502 \mathrm{cal} / \mathrm{g} \\
& 85-50 \mathrm{wt} \% \mathrm{BaCrO}_{4} \\
& 502 \mathrm{cal} / \mathrm{g} \text { for } \sim 60 \mathrm{wt} \% \mathrm{BaCrO}_{4}
\end{aligned}
$$

Fig. 1. Use of zirconium in thermal batteries [16].

oxides of iron, cobalt, and vanadium were used to produce different cermets. The authors also explored the combustion synthesis of silicides, borides, and carbides. The use of beryllium as a reducing agent and reduction of uranium oxide were discussed. Several other researchers made attempts to synthesize other materials like aluminum phosphide by direct reaction between red phosphorous and aluminum powders [21], tantalum metal by reduction of $\mathrm{K}_{2} \mathrm{TaF}_{7}$ with sodium [22], and the formation of molybdenum disilicide by direct reaction between molybdenum and silicon powders [23]. In 1964, Krapf [24] patented the chemical hot press in which a mixture of reactive powders was heated in a die by passing an electric current. After initiation of exothermic reaction, the product was pressed by a uniaxial force. The concept of pressing hot products generated in strongly exothermic reaction was also described in 1967 by Stringer and Williams [25]. According to these authors, reaction pressing can be applied to intermetallic and metal-metalloid compounds generated by fast evolution of energy due to a chemical reaction between reactant powders. They claimed that the exothermic effect of reaction in many cases is sufficient to form plastic product mass which can be quickly formed to different shapes. The authors emphasized the use of aluminides, berrilides, titanides, zirconides, and borides. In 1968, McKenna [26] patented a process of preparing tungsten monocarbide utilizing exothermic effect generated during the reaction between elemental powders. In 1973, Hardt and Phung [27] published a very important paper on propagation of gasless reactions in solids, which further alerted US scientists about importance of the combustion synthesis.

\section{COMBUSTION SYNTHESIS RESEARCH IN USA AFTER 1980}

After sporadic activities in Western World in the 50s and 60s, a more significant research effort was made in the United States starting in early 1980s. In 1982, McCauley et al. [28, 29] and Holt and Kingman [36] published new results in the area of combustion synthesis, which generated interest at several universities and US government laboratories. The review paper on the SHS activities in Soviet Union written by Crider [37] also stimulated a renewed interest. The work of McCauley et al. [29] was initiated from comprehensive investigation of burning characteristics of zirconium metal with air and barium chromate for the potential use of this reacting system in thermal batteries [16, 35]. The basic schematics of a thermal battery and key gasless and gas-solid SHS reactions are shown in Fig. 1.

Following this work on zirconium burning characteristics [35], McCauley and his co-workers [28-36] shifted their activities from using by-products of SHS to processing, focusing on the following: (i) utilize reaction sintering concepts without pressure, (ii) importance of physical and chemical characteristics of powders, (iii) focus on phase equilibrium, and (iv) detailed characterization of final sintered products.

Critical issues in reaction sintering are as follows:

- chemical driving forces much higher than conventional sintering,

- if gas forms most diffuse out,

- volume fractions of reactants and products change with time,

- Kirkendall effects: porosity formation due to density change between reactants and products,

- wetting between liquids and solid phases becomes important, 
- grain size reduction from reactants-nucleate new phases.

A pioneering work of Holt and Kingman [36] was mainly focused on combustion synthesis of ceramic powders and refractory materials in general, which was more aligned with the research activities conducted in the former Soviet Union's laboratories.

A turning point in the United States efforts in SHS was catalyzed by a major contract from the Defense Advanced Research Projects Agency (DARPA) that was carried out during 1984-1986. The overall contract manager was J.W. McCauley and the program manager was J.B. Holt at the Lawrence Livermore National Laboratory with sub-contracts at The University of California, Davis, Ceramatec, Los Alamos National Laboratory, and Rice University.

The key universities, which started research in combustion synthesis in early 1980s included: University of California at Davis, Georgia Institute of Technology, State University of New York at Buffalo, and Northwestern University. These early research activities were supported by National Science Foundation, Department of Energy (Los Alamos National Laboratory and Sandia National Laboratory), and US Army. Also, some research in the area of combustion synthesis was conducted in US government laboratories, especially Department of Energy, US Army, and US Navy. In the table, the summary of research activities in academia, government laboratories, and industry in the United States at the end of 1980s is presented.

Both theoretical and experimental efforts were undertaken to explain various phenomena of combustion synthesis. Theoretical research describing combustion front stability and bifurcation analysis was done by Matkowsky from Northwestern University, and Margolis, Armstrong and Koszykowski from Lawrence Livermore National Laboratory. Professor Matkowsky has published numerous theoretical papers on the subject of gasless and gas-solid reactions [38-52]. His pioneering work with Margolis, Kaper, and Leaf on bifurcation on pulsating and spinning reactions in condensed twophase combustion belongs to very fundamental classics of combustion synthesis [39]. His further analysis with Bayliss of two routes to chaos in condensed phase combustion as well as a series of theoretical papers on filtration combustion with Booty and scientists from Chernogolovka, Russia made very significant contribution to better understanding of complex nonlinear phenomena in combustion synthesis. Very accomplished mathematicians and theoreticians, such as Shkadinsky, Shkadinskaya, Aldushin, and Volpert from Russia cooperated closely with Professor Matkowsky during the 1990s. Dr. Volpert joined Northwestern University and he presently works there as a professor of applied mathematics. Professor Volpert published several papers with Professor Matkowsky on the theory of gasless and various aspects of filtration combustion in porous structures with and without deformation. He also contributed to better understanding of combustion in microgravity environments and mathematical modeling of frontal polymerization and understanding of wave propagation during free-radical polymerization with the gel effect [53-63].

A parallel mathematical modeling effort was undertaken at the State University of New York at Buffalo under the leadership of Professor Hlavacek who joined that university in 1981. Professor Hlavacek established a very active research group which focused its research on both experimental studies and mathematical modeling of self-sustaining reactions and materials engineering aspects of combustion synthesis. Due to the access to parallel computer processors in mid 1985, his research modeling team was able to simulate complex combustion patterns, including transition to chaos, breaking of symmetry, fingering effects, multiple spinning waves in two and three dimensions, as well as complex behavior of the combustion front during gassolid reactions [64-76]. Figure 2 shows the transition to chaos via period doubling in gasless reacting systems. A typical sequence of spinning combustion waves in two dimensions is shown in Fig. 3. It should be noted that these simulations were done using a very sophisticated adaptive mesh computer program, which allowed completing calculations on available supercomputers within a reasonable period of time. This computer technology looks old today, but truly it was the state-of-theart twenty years ago.

In the 1990s, Professor Law from Princeton University published a number of papers describing model formulations, mathematical modeling of combustion front propagation and comparison of key combustion characteristics with experimental results [77-87]. Figure 4 shows comparison of experimental and theoretically predicted combustion limits for the Co-Ti system [82].

During the same period of time, other researchers from various universities also contributed to development of new reaction models and mathematical modeling of combustion synthesis processes. Contributions by Professors Munir, Stangle [88], Kanury [89], Bhattacharya [90], and Varma [91] are also of very significant importance.

The experimental research conducted in the US national laboratories and US universities resulted in many accomplishments, which led not only to significant contributions into the fields of physics, materials science, ceramic engineering, and reaction engineering but also to the development of several technologies, which resulted in their commercialization.

In academia, Professor Munir, one of the key SHS leaders in USA has been involved in the area of combustion synthesis from the early 80 s. His research activities at University of California at Davis resulted in education of large number of excellent scientists who are 
SHS R\&D groups in the United States in late 80 s

\begin{tabular}{|c|c|c|}
\hline Organization & Principal investigators & Technology focus \\
\hline \multicolumn{3}{|l|}{ Department of Defense } \\
\hline Army Material Technology Lab. & Croft, Marzik, McCauley & Powder characterization, sintering, phase equilibria \\
\hline Army Ballistic Research Lab. & Niiler, Kottke & Dynamic compaction, modeling \\
\hline Army Research Office & Crowson & Coordination and management \\
\hline \multicolumn{3}{|l|}{ Department of Energy } \\
\hline Los Alamos National Lab. & Behrens & High-temp, chemistry, laser ignition, modeling \\
\hline Lawrence Livermore National Lab. & Holt, Halverson, Chow & SHS, bulk materials, models \\
\hline Sandia National Lab. & Margolis & Modeling \\
\hline \multicolumn{3}{|l|}{ Academia } \\
\hline Alfred University & Spriggs & Materials processing, reviews \\
\hline Oregon State University & Kanury & Modeling \\
\hline Washington State University & Wojcicki & Materials processing, eutectics \\
\hline University of California Davis & Munir & SHS, materials processing, fundamentals \\
\hline Northwestern University & Matkowsky & Mathematical analysis \\
\hline Georgia Tech. Research Institute & Logan & SHS, materials processing, thermites \\
\hline Rice University & Margrave & High temperature mass spectrometry \\
\hline New Mexico Inst. of Mining \& Tech. & Thadani & Explosive compaction \\
\hline State University of NY Buffalo & Hlavacek, Puszynski & SHS, powders, mater, processing, math. modeling \\
\hline University of California San Diego & Meyers & Explosive compaction \\
\hline University of Florida & Clark, Dalton & Microwave processing \\
\hline Colorado School of Mines & Moore & SHS, intermetallics \\
\hline \multicolumn{3}{|l|}{ Industry } \\
\hline Research Triangle Institute & Mullins & Fibers and metal matrix composites \\
\hline CERAMETEC & Cutler & SHS, powders, thermites \\
\hline General Sciences Inc. & Zavistanos & SHS densification \\
\hline System Planning Corp. & Frankhouser & Reviews and analyses \\
\hline Lockhead Corp. & Hardt & SHS, sintering; phase equilibria \\
\hline Corning Glass Works & DeAngelis & Reactive hot pressing \\
\hline W.R. Grace & Rice & Materials processing \\
\hline Advanced Refractory Technologies & Blakely & SHS powders, whiskers \\
\hline Innovative Materials, Inc. & Puszynski, Hlavacek & SHS; nitride, boride, and carbide ceramics; intermetallics \\
\hline Benchmark Structural Ceramics & Hida & SHS powders and whiskers \\
\hline Powder Technologies, Inc. & Logan & SHS powders and bulk materials \\
\hline Synergetic Materials, Inc. & Halverson & Advanced materials \\
\hline Kiser Research, Inc. & Kiser & Soviet SHS technologies \\
\hline
\end{tabular}

working in many countries. His selected major research contributions are listed below [92-105]:

- combustions synthesis of refractory carbides, borides, silicides, nitrides, and intermetallic compounds (1980s),

- analysis of the role of thermal migration in pore formation during SHS synthesis (1990),

- theoretical analysis of the stability of self-propagating combustion synthesis waves, concept of SHS diagrams (1990-1992),
- use of the Boddinton-Laye mathematical analysis for direct determination of kinetic parameters during SHS (1992),

- analysis of the origin of porosity in SHS products (1993),

- the role of electric fields in SHS reactions: modeling and experimental work (1995-1998),

- separation of the thermal (Joule heat) from the intrinsic (electron wind effect) contributions of the field (current), work on electromigration has demonstrated 
Front velocity, $v_{f}$
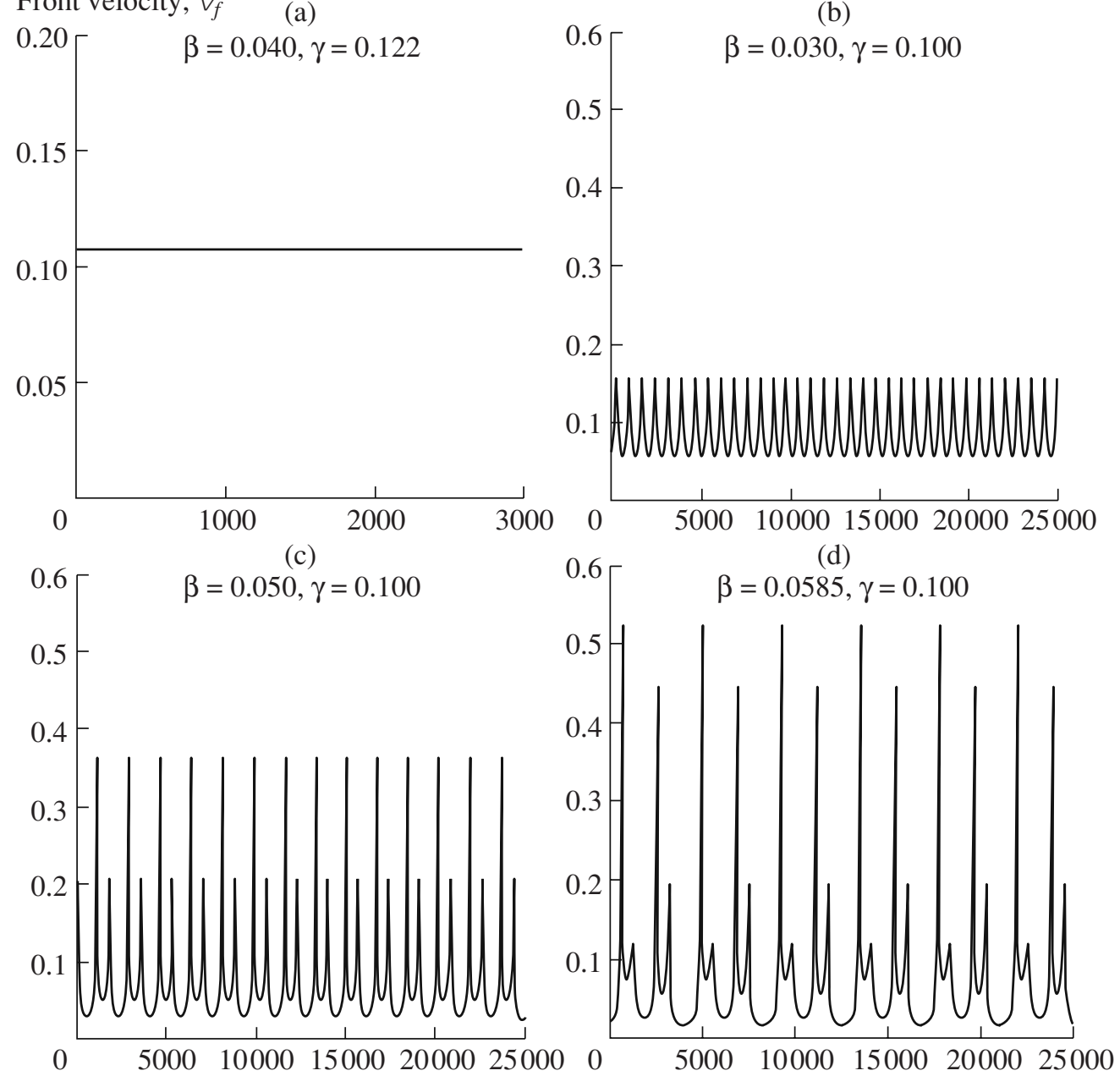

(e)
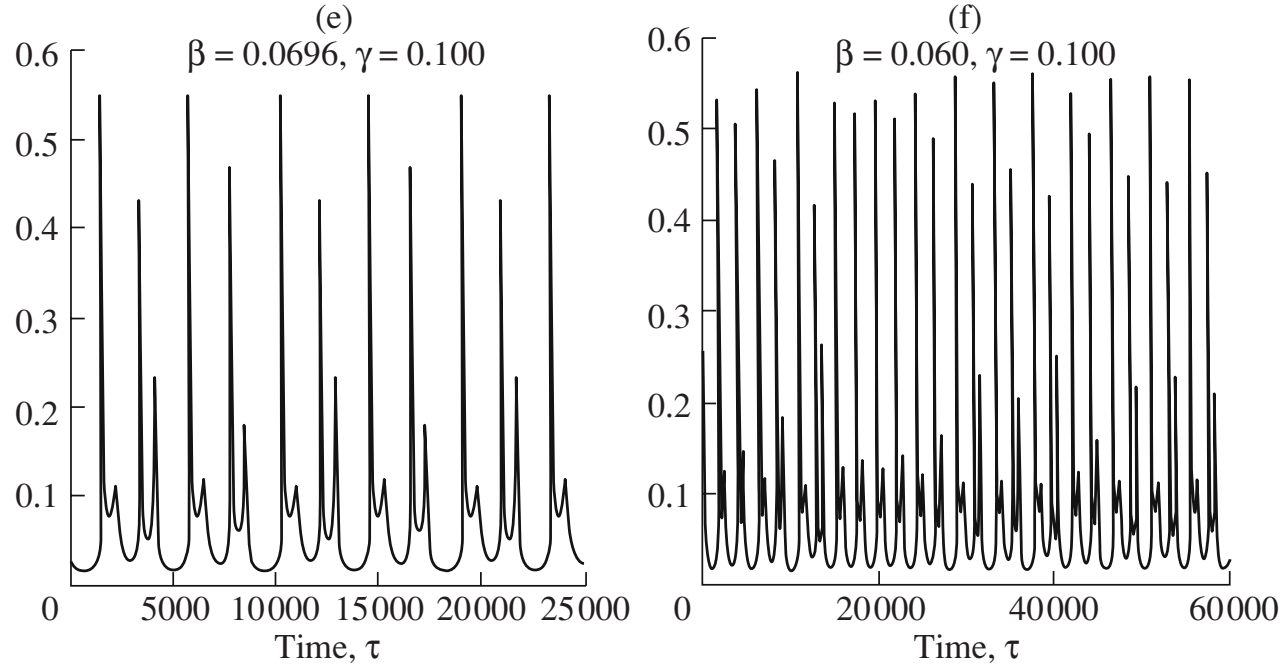

Fig. 2. Combustion front propagation velocity $v_{f}$ in gasless systems with different dimensionless activation energy and heat of reaction vs. time $\tau[68]$.

field effect on point defect generation and mobility (2001),

- recent work on the combined mechanical and field activation to synthesize dense (bulk) nano-ceramics and nano-composites in one step (2001—present),
- use of field activation for simultaneous synthesis and consolidation of complex materials $\left[\mathrm{Ti}_{3} \mathrm{SiC}_{2}\right.$ (1999), $\mathrm{TiB}_{2}-\mathrm{WB}_{2}-\mathrm{CrB}_{2}$ (2001), AlN-SiC (1996-2000)],

- use of field activation for microalloying (20032004), 
(a)

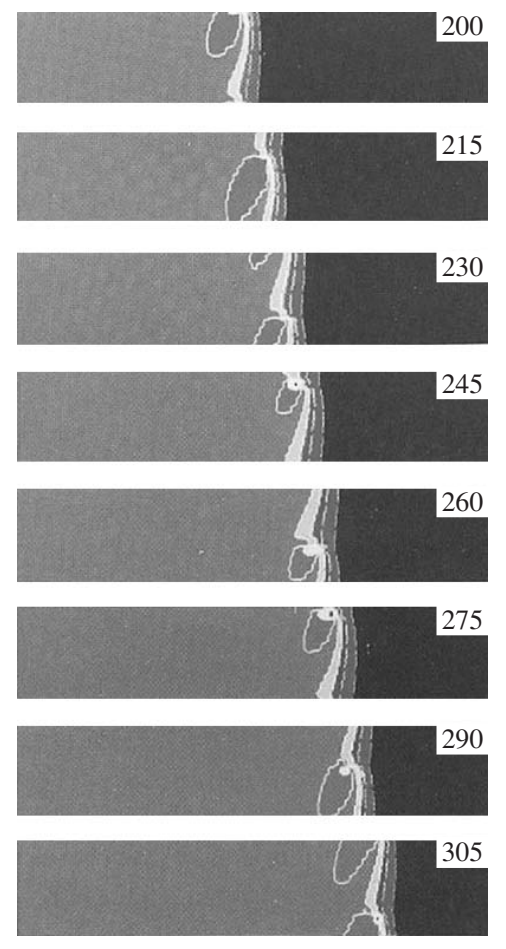

(b)
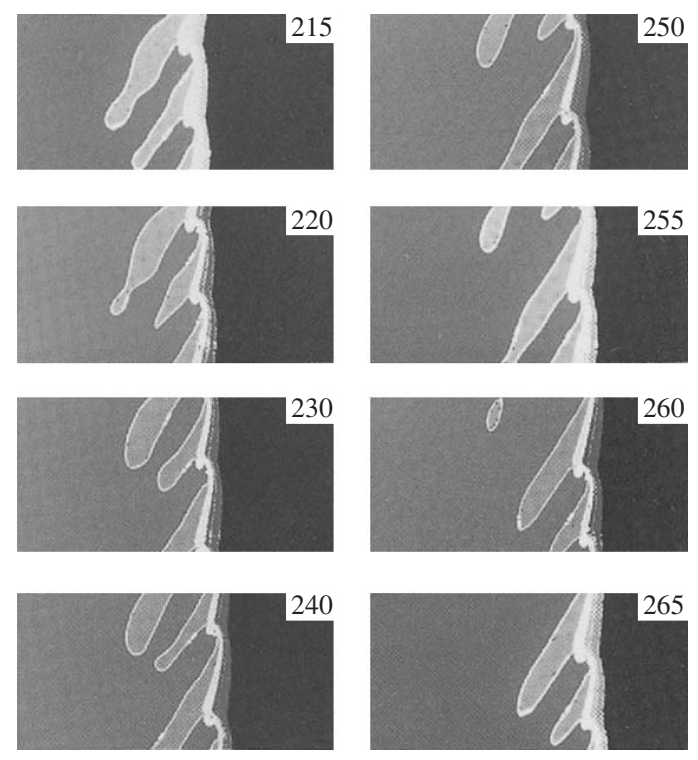

Fig. 3. Two-dimensional modeling: (a) single head spinning wave and (b) multiple head spinning waves [64].

- use of field activation to prepare nanostructured functional oxides for fuel cell applications: novel demonstration of power generation at room temperature by protonic conduction.

The main advantage of the field-assisted process is the electrical discharge at particle contacts which promote sintering. Numerous materials, including TiN, $\mathrm{TiO}_{2}, \mathrm{SiC}, \mathrm{Si}_{3} \mathrm{~N}_{4}-\mathrm{TiN}, \mathrm{ZrO}_{2}-\mathrm{Al}_{2} \mathrm{O}_{3}$, and FeAl, were sintered during the past several years resulting in the formation of dense articles with nanosize grains. The starting powders were obtained by plasma, mechanical alloying, or sol-gel techniques. A very important modification of this field-assisted technique was presented by Munir [93]. It was demonstrated that the combination of field-assisted technique, such as SPS, and in-situ synthesis of materials from nanoreactants or mechanically activated powders may result in the formation of desired phase and consolidated products retaining nanostructure. Experimental results did show that the presence of electrical field influences on the mechanism and rate of the condensed phase reaction as well as the phase composition and elemental distribution in solid solutions. The main effects of the electric field during the reaction have been attributed to Joule heating, enhanced mass transport by electron-migration, and the formation of plasma on the particle level. Therefore, the entire process of in-situ densification of combustion synthesized bulk materials exhibiting a nanostructure can be divided into three steps:
- mechanical activation of participating reactants,

- cold compaction of pre-alloyed powders,

- field-activated pressure-assisted synthesis.

In the first step, reactant powders are mixed in a stoichiometric ratio and co-milled in a planetary mill in order to form nanocrystallites. During the milling, the particles are flattened, fractured, and welded. This process of grain size reduction, generation of residual stresses, and phase transformation has a significant effect on the kinetics of combustion reactions during the final consolidation step in the presence of electrical field.

The second step involves cold-compaction of mechanically activated powders into a graphite die. The final step includes simultaneous application of electric current and uniaxial pressure under the inert atmosphere. In this step, the combustion reaction is initiated by Joule heating and the hot product is densified within a few minutes. Relative densities between $90-100 \%$ of the theoretical density can be commonly achieved.

It should be mentioned that Professor Munir has published many papers and obtained numerous patents for his innovations of combustion synthesis. In this review only few selected papers are mentioned [92105]. He has also made very important contribution to the SHS community by reviewing articles on SHS for many journals, including the Ceramic Bulletin, and Materials Science Reports, which are cited by thou- 

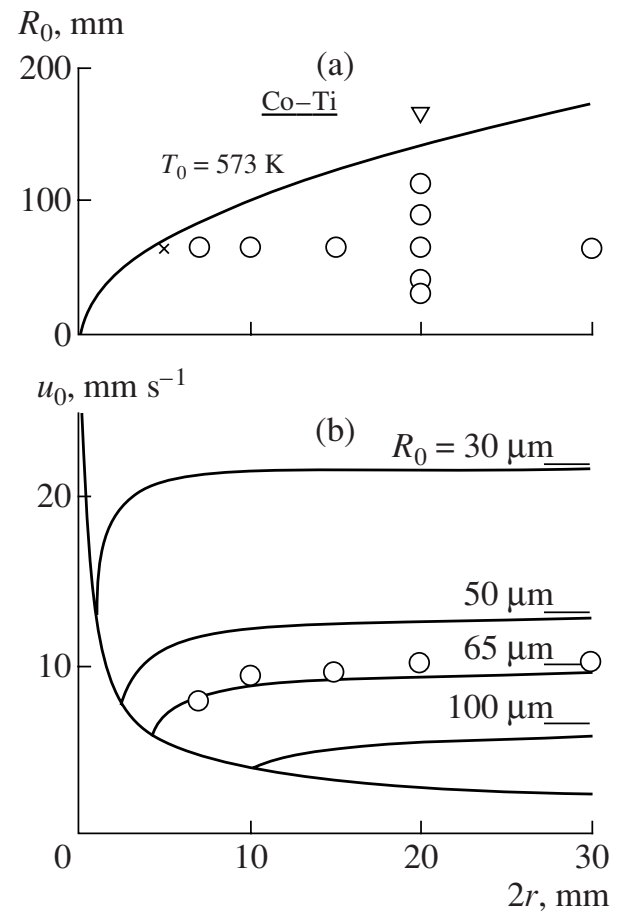

Fig. 4. Nanodiabatic combustion behavior for the Co-Ti system with stoichiometric mixture at $T_{0}=573 \mathrm{~K}$ : (a) Range of flammability as a function of $2 r$ and $R_{0}$, data are from Itin et al.; $(\bigcirc)$ designates the steady propagation, $(\square)$ the flame extinction during the propagation, and $(x)$ the nonignition. (b) Burning velocity $u_{0}$ as a function of $2 r$, with $R_{0}$ taken as a parameter, data points are experimental in the literature.

sands and continue to be cited to the present. Professor Munir has established among US scientists the strongest collaboration with researchers around the world. He has collaborated with Professors: Frederic Bernard, University of Burgundy, Dijon, France; Manshi Ohyanagi, Ryukoku University, Seta, Japan; Umberto Anselmi-Tamburini, University of Pavia, Italy; Giacomo Cao, University of Cagliari, Italy; Manfred Martin, University of Aachen, Germany; Rainer Telle, University of Aachen, Germany; In-Jin Shon, Chonbuk National University, Korea; Myeong-Woo Cho, Inha University, Korea; Roberto Tomasi, Sao Carlos Federal University, Brasil; Qing-sen Meng, Taiyuan University of Technology, China; K.A. Khor, Nanyang Technological University, Singapore; Z.Y. Fu, Wuhan University of Technology, China; and Yu. Maksimov, Tomsk University, Russia. He has also ongoing collaboration with US national laboratories, including collaboration with Dr. Alex Gash from Lawrence Livermore National Laboratory, USA and Dr. John Neal from Oak Ridge National Laboratory, USA. Professor Munir has published many papers and he was awarded with numerous patents related to combustion synthesis. In 1993, he established the American Consortium of Combustion Synthesis.
The State University of New York at Buffalo (SUNY/Buffalo) was the second university strongly involved in combustion synthesis research. As indicated before, Professor Hlavacek built a very large group of $\mathrm{PhD}$ students and research scientists. His integrated approach resulted in a strong development of combustion synthesis technologies supported by strong basic experimental research and mathematical modeling programs [106-117]. In the mid 80s, Drs. Hlavacek and Puszynski successfully transferred the technology of synthesizing aluminum nitride by combustion synthesis technique into Advanced Refractory Technologies Company located in Buffalo, NY. This company was the first to produce aluminum nitride by this technique. In the late 1980s, other technologies for synthesis of silicon nitride, titanium carbonitride, $\alpha$ - and $\beta$-sialons, titanium carbide-titanium boride and silicon nitride-silicon carbide composites as well as tungsten carbide and aluminum phosphide were developed by Drs. Hlavacek and Puszynski. The university spin-off company Ceramic Materials Processing, Inc. was involved in manufacturing of ceramic and intermetallic powders by SHS method, scale-up of combustion reactors, and technology transfer. During the 80s and early 90s, several researchers visited SUNY/Buffalo. Dr. Puszynski joined Professor Hlavacek's group in 1982. In 1991, Puszynski accepted a position at the South Dakota School of Mines and Technology where he has been continuing SHS-related work. His research has been focused on combustion synthesis of nanopowders and nanocomposites as well as the reaction kinetics in systems consisting of nanosize reactants [118-126]. Professor Puszynski established close cooperation with Yerevan State University in Armenia, Academy of Mining and Metallurgy in Cracow, Poland and several US national laboratories. His recent work indicates that various intermetallic composites reinforced with single wall carbon nanotubes can be formed in a self-sustaining regime with the ultimate grain structure being at the nanoscale (see Fig. 5). His comprehensive work on combustion synthesis in the $\mathrm{Si}-\mathrm{Al}-\mathrm{Ti}-\mathrm{O}-\mathrm{N}-\mathrm{C}$ system has led to the formation of many complex compounds with different morphologies and phase compositions. His work on chemically-assisted gas transport combustion synthesis led to successful synthesis of nanosize silicon carbide. Figure 6 shows inert gas pressure regimes where silicon carbide can be formed. Figure 7 shows different morphologies of silicon nitride formed with and without the presence of gas-transport promoting additives.

Professor Puszynski has been actively involved in the organization of technical sessions dedicated to combustion synthesis at various conferences, including the American Institute of Chemical Engineers and the American Ceramic Society. Professor Puszynski also serves as a frequent reviewer of journal manuscripts. He also serves as a consultant to Noveltec Co. in Tennessee, which is involved in production of variety prod- 

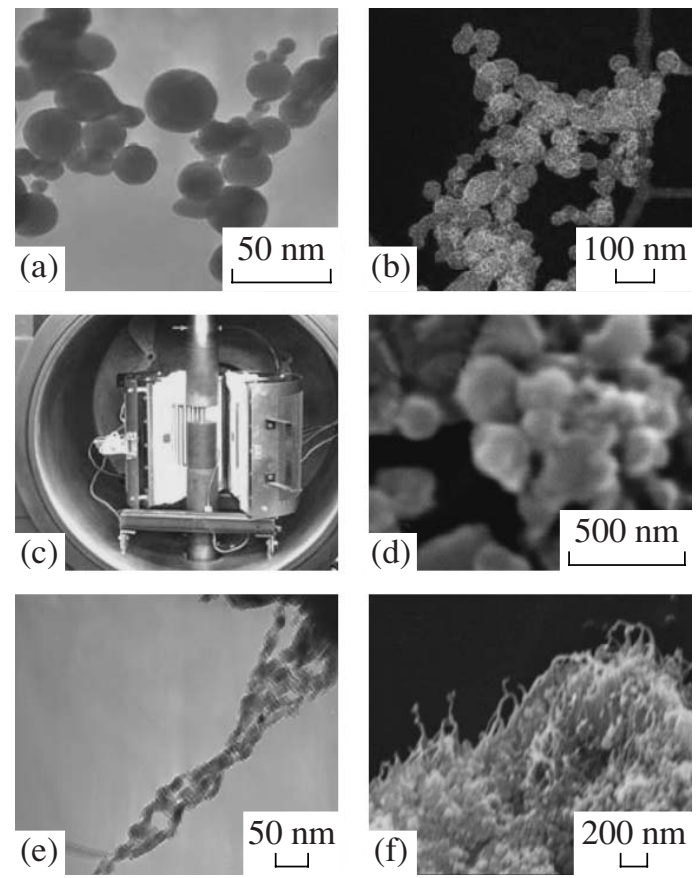

Fig. 5. (a), (b) TEM images of $\mathrm{Al}$ and Ni nanoreactants, (c) reaction chamber, (d) SEM image of nanosized nickel aluminide-alumina composite prepared by simultaneous combustion synthesis and densification, (e), (f) SEM images of single-walled carbon nanotubes reinforced nickel aluminide-alumina nanocomposites.

ucts, including sialons, carbides, borides, nitrides, and sulfides by the SHS technique.

Dr. Viljoen spent several years at SUNY/Buffalo in the late 1980s and early 1990s. Dr. Viljoen work in the SHS area was focused on fundamental aspects of combustion reactions involving the solid state. After accepting a professor position at University of Nebraska, he continued his fundamental work focusing on solidsolid reactions with mechanical coupling, understanding of solitons and non-equilibrium reactions in solid phases, combinatorial approach to surface contacts in solid-phase reactions, and analysis of the effect of heat transfer on combustion front propagation limits [127131]. Professor Viljoen also contributed to a better understanding of strongly exothermic reaction taking place under strong compression. He also cooperated with Russian scientists, including Dr. Schteinberg, and he supervised several Russian graduate students who joined his research group.

Dr. Lis joined Professor Hlavacek's research group in the late 1980s. His research at SUNY/Buffalo was focused on combustion synthesis of silicon nitride-silicon carbide composites and sialons. He published jointly with Professor Hlavacek and his key staff several papers, which outlined key aspects of combustion synthesis, processing, and sintering of SHS synthesized materials. After his return to Poland, he continued
Argon pressure, atm

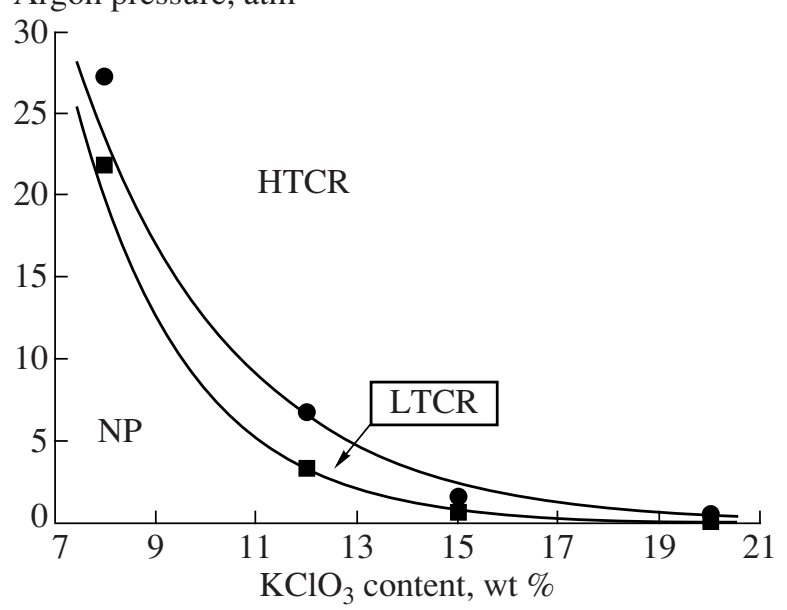

Fig. 6. Combustion propagation diagram in $\mathrm{Si}-\mathrm{C}-\mathrm{KClO}_{3}$ reacting system: NP means no propagation; LTCR stands for low temperature combustion regime; and HTCR, for high temperature combustion regime.

building SHS related programs together with his former $\mathrm{PhD}$ advisor Professor Pampuch. Later, the group headed by Professors Pampuch and Lis became one of the most active European groups outside the former Soviet Union. It should be clearly noted that Professor Hlavacek educated many excellent Ph.D students who are currently working in the industry or academia. He also was the pioneer who introduced many chemical engineers into the field of combustion synthesis.

In the late 1980s and at the beginning of 1990s, several other US universities got involved in combustion synthesis research. In the early 1990s, Alfred University under the leadership of Drs. Spriggs and McCauley initiated a research program focusing on further development of SHS technologies. With the strategic hiring of Dr. Stangle, several R\&D initiatives were conducted, including: (i) fabrication of dense $\mathrm{MoSi}_{2}$ and $\mathrm{MoSi}_{2}$ based composites using SHS process, (ii) combustion synthesis and fast-firing of nanocrystalline yttria-stabilized zirconia, (iii) fabrication of functionally gradient materials by SHS method (see Fig. $8[156,157]$ ), (iv) development of a centrifugal SHS process and analysis of its fabrication capabilities, (v) investigation of the mechanism and kinetics of combustion synthesis, and (vi) study of the combustion synthesis process for materials fabrication. This multi-year research program resulted in thirty-one publications and international recognition of an established research center [132162].

In addition, the Alfred group established several international collaborations:

- interactions and formal agreement with NRIM, Japan (Kaieda), 

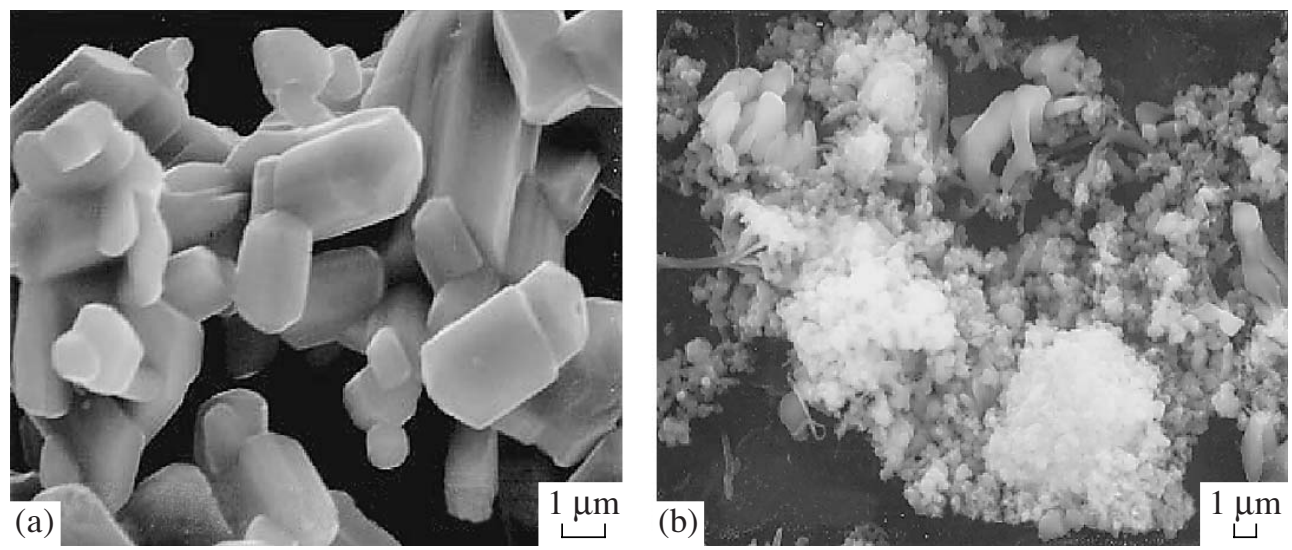

Fig. 7. SHS produced $\beta-\mathrm{Si}_{3} \mathrm{~N}_{4}$ (a) and $\alpha-\mathrm{Si}_{3} \mathrm{~N}_{4}$ (b).

- formal agreement with the Institute of Materials Science, School of Mining and Metallurgy, Poland (Pampuch),

- interactions and formal agreement with ISMAN (Merzhanov and Borovinskaya).

At approximately the same time period, Professor Varma initiated combustion synthesis research at Notre Dame University. His initial research interest was focused on mathematical modeling of combustion fronts. However, very quickly his research evolved toward experimental investigation of reaction kinetics of heterogeneous reactions as well as understanding of system heterogeneity and melting effects on propagation of combustion fronts in the condensed phase [163177]. Professor Varma invited a few Russian scientists, including Drs. Mukasyan and Rogachev, to work with

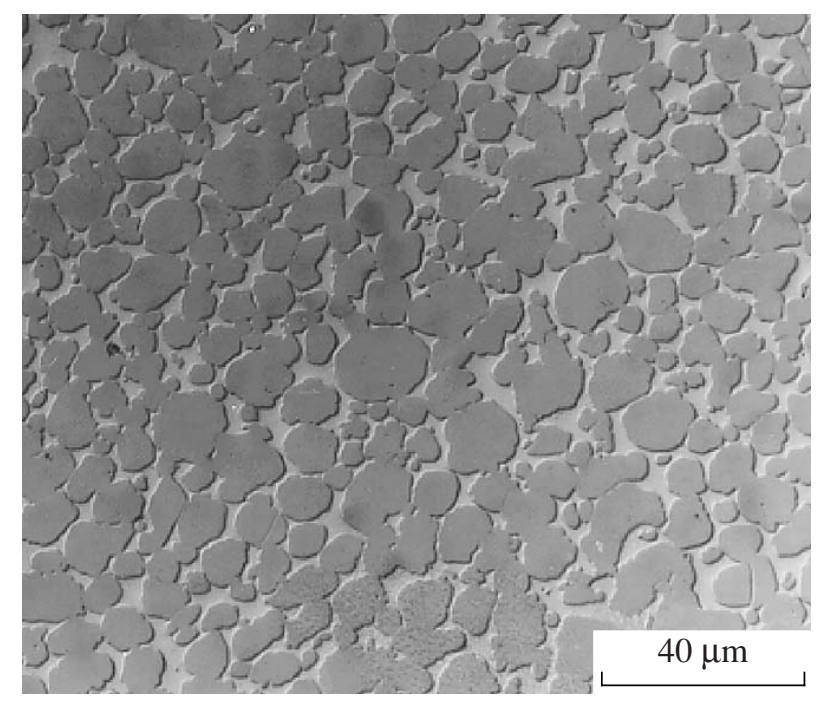

Fig. 8. Microstructure of in-situ densified $\mathrm{TiC}-25 \% \mathrm{Ni}$ composite formed during combustion synthesis and obtained in Prof. Meyers' laboratory. him at Notre Dame University. He also attracted several graduate students, including some from Russia. Dr. Mukasyan was offered a permanent position at this university and he is still working there conducting his own research program in the area of combustion synthesis. A few years ago, Professor Varma accepted a new challenging position at Purdue University where he continues research in the area of strongly exothermic non-catalytic reactions. Both Professors Varma and Mukasyan when working together at Notre Dame University conducted combustion synthesis research in a microgravity environment. They also investigated possibilities of synthesizing biomaterial using the SHS technique. They also initiated work on combustion solution of oxide nanomaterials for development of catalysts. Presently, Professor Mukasyan is actively continuing that research. A variation of the combustion synthesis process, namely utilization of exothermic redox reactions in solutions, was already investigated by several researchers in India and in the USA. Professor Bhaduri was among first who explored this technique in USA [178-182]. This type of the reaction is called solution combustion synthesis (SCS) and involves a self-sustaining reaction between metal nitrates and carbonaceous fuels, such as urea, glycine or carbohydrazide. The reaction between such fuel and oxygen containing species results in a significant heat generation. In practice, this process is accomplished by dissolution of metal nitrates and uniform mixing of the fuel and nitrates in water, preheating of the oxidizer-fuel solution with subsequent water vaporization, followed by self-ignition of the dry reactants. As a result, the formation of crystalline oxide nanopowders with tailored compositions can be formed. The main advantage of this approach is mixing of reactants at the molecular level. The overall reaction process is very fast and results in the formation of nanograins exhibiting a high purity due to vaporization of all volatile species at high reaction temperatures generated by this exothermic reaction. Another important advantage of this method is a possibility of the formation of complex oxide nanop- 
owders for different applications as structural ceramics, catalysts, bio- or fuel cell materials [183-188].

The combustion synthesis research at Colorado School of Mines has been carried out by Professor Moore for almost twenty years. Professor Moore's research interest has been on the formation of composite materials at normal or reduced gravity environments. The recent research interest of Professor Moore is focused on the formation of biomaterials [189-192]. Professor Moore is very actively involved in numerous professional societies and his published contributions into the field of SHS are highly regarded by the international SHS community.

A significant research effort in the USA was focused on simultaneous combustion synthesis and hot pressing. Professor Logan from Georgia Institute of Technology established an experimental program focusing on densification of titanium diboride and various composites generated during aluminum thermal reduction of oxides [193]. Professor Logan developed a strong cooperation with the R\&D group led by Dr. Niiler from US Army Ballistic Laboratory and McCauley of the US Army Materials Technology Laboratory. Niiler and his co-workers were involved in shock densification of combustion synthesized materials by means of explosives [194, 195].

Shock-induced densification of ceramics and cermets by unique high speed forging was conducted by Professor Meyers and his research group at University of San Diego, CA [196-211]. Professor Meyers contributed to elucidation of the reaction mechanism at the front in the Ti-C system. This work was done with Dr. LaSalvia from the US Army Research Laboratory and produced some outstanding results describing physicochemical mechanism of that reaction [200, 201]. Professor Meyers also contributed to fundamental understanding of densification by quasi-isostatic pressing (QIP) of reaction products. This work was done in collaboration with Professor Olevsky [210, 211]. The use of a granular pressure transmitting medium, initially introduced at Chernogolovka, was used to produce TiC plates with dimensions of $12 \times 12 \times 2$ inches. Production and densification of TiC-NiTi cermets was another accomplishment of this technology. Figure 8 shows a typical microstructure of $\mathrm{TiC}-25 \% \mathrm{Ni}$ composite material formed by SHS dynamically densified material. Professor Meyers collaborated with Dr. Kim, South Korea, Professor Meyer, Chemnitz University, Germany, Dr. Ramas Raman from Ceracon, Professor Olevsky, San Diego State University, and Dr. Jamet from Ecole Centrale de France.

A significant contribution into the area of shock densification of combustion synthesized intermetallics and ceramic materials was also made by Professor Thadani [212-217].

Recently, Professor Luss and his co-workers developed a novel efficient synthesis method named carbon combustion synthesis of oxides (CCSO) for production of advanced nano and submicron complex oxides such as ferroelectrics $\left(\mathrm{BaTiO}_{3}, \mathrm{SrTiO}_{3}\right)$, hard and soft magnetic materials ( $\mathrm{Ba}, \mathrm{Sr}, \mathrm{Pb}, \mathrm{Mn}-\mathrm{Zn}$ and $\mathrm{Ni}-\mathrm{Zn}$ ferrites), superconductors $\left(\mathrm{Y}_{123}\right)$, optoelectronics $(\mathrm{ZnSnO})$, solid-oxide fuel cell components $\left(\mathrm{LaGaO}_{3}\right)$, battery electrodes $\left(\mathrm{LiMn}_{2} \mathrm{O}_{4}\right)$, catalysts, membranes, and digital pigments [218-221]. The method is a modification of self-propagating high temperature synthesis (SHS) that uses carbon as the heat generating fuel instead of a pure metal. The concentration of the carbon in the reactant mixture enables control of the moving front temperature and average temperature front velocity as well as the products particle size and surface area. CCSO may be used to produce oxides even when SHS cannot be applied, such as when the pure metal is pyrophoric (such as $\mathrm{Li}$ or $\mathrm{La}$ ) or that it melts at room temperature (for example, Ga), or when the metal heat of combustion is relatively low. In contrast to the common SHS, the combustion product (carbon dioxide) is not incorporated into the product and exits from the sample. Moreover, the lubricating properties of carbon enhance the mixing by ball milling. The high rate of $\mathrm{CO}_{2}$ release increases the porosity of the particles and the friability of the powder. The process is significantly faster than common calcinations processes and produces powders with smaller particle size.

Another interesting activity conducted by this group is focused on spontaneous magnetization generated by solid state combustion [222-228]. Using a highly sensitive high- $T_{\mathrm{c}}$ superconducting quantum interference device (SQUID), they were able to conduct the first measurement of the very low intensity (order of nT) transient magnetic field formed by a combustion front motion. The front propagation generated a slowly oscillating magnetic field on which, in some cases, high frequency small oscillations were superimposed. The magnetic power spectra of the oscillations scaled as a power law, suggesting that they are associated with a stochastic process. The combustion synthesis of ferrites generated qualitatively different magnetic fields under different modes of combustion front motion i.e., planar, spin, and pulsating. The average magnetization vector generated by either planar or pulsating combustion was oriented at a smaller angle with respect to the pellet axis $\left(\phi \leq 45^{\circ}\right)$ than those generated by spin combustion $\left(60^{\circ} \leq \phi \leq 80^{\circ}\right)$. The Earth's magnetic field had no impact on the spontaneous magnetization field of the samples. Dr. Luss' research group also developed a simple electromagnetic model which predicted the qualitative features observed in the experiments. The transient evolution of this field depends on whether the combustion temperature exceeds or does not exceed the Curie temperature. Figure 9 shows a case in which a residual magnetic field of about $4 \mu \mathrm{T}$ was generated by the spontaneous magnetization of the ferromagnetic product $\mathrm{PbFe}_{12} \mathrm{O}_{19}$ in the post-combustion zone. The characteristic spontaneous magnetic field saturation time of about $250 \mathrm{~s}$ was much longer than the 1-2 s 


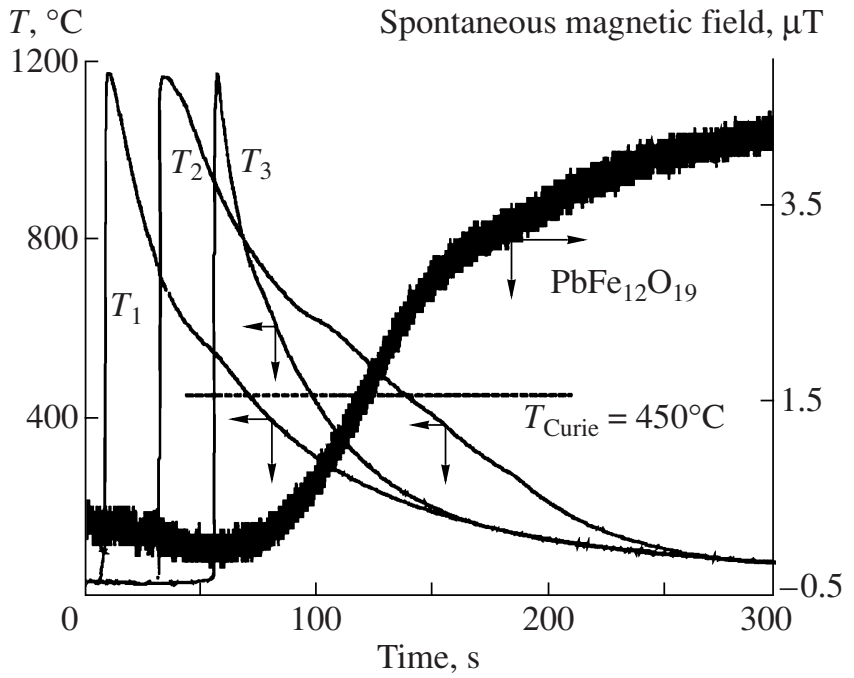

Fig. 9. Three temporal combustion temperatures in the top $\left(T_{1}\right)$, middle $\left(T_{2}\right)$, and bottom $\left(T_{3}\right)$ of the sample and the spontaneous magnetic field measured near the one side of the sample during the combustion synthesis of ferrite. The distance between surface and sensor was $10 \mathrm{~mm}$ [226].

duration of the electrical signal. The magnetic field was created by three different mechanisms: (i) orientation of the magnetic dipole moments by internal electrical field force, (ii) dipole self-orientation along existing residual field of the bulk material during the cooling, and (iii) via chemisorption of $\mathrm{O}_{2}$ molecules on the ferromagnetic surface.

During the past several years, another interesting technology was developed by Dr. Weihs from John Hopkins University [229-231]. Multilayer reactive foils provide ideal sample geometries for studying different SHS reaction with a high level of contact between reactants. In addition, the thickness of each layer can be precisely adjusted. Currently, his technology is used by Reactive Nanomaterials Co. for bonding dissimilar materials and in other applications.

\section{SUMMARY}

This review clearly indicated that the contribution of US scientists to both theoretical understanding of combustion reactions in condensed phase and development of new innovative technologies based on the principle of self-propagating reactions between solid reactants or those involving solid and gas interactions is significant. Despite the relatively small number of researchers involved in this field, the number of publications, patents, as well as technological know-how development is quite impressive.

Forty years have passed since the discovery of SHS in 1967. It should be emphasized that during the last seventeen years the exchange of information among all scientists working in combustion synthesis is without the political barriers that existed until the early 1990s.
Every two years, researchers have the opportunity to present their results at international SHS symposia. New close cooperation agreements have been established between different universities and research institutes. We hope that this trend will continue and new generations of scientists and engineers will contribute into the field of SHS freely and without any external constraints.

\section{REFERENCES}

1. Merzhanov, A.G., Shkiro, V.M., and Borovinskaya, I.P., A Method for Synthesizing Refractory Compounds, USSR Inventor's Certificate no. 255221, 1967.

2. Merzhanov, A.G. and Borovinskaya, I.P., Self-Propagating High-Temperature Synthesis of Refractory Inorganic Compounds, Dokl. Akad. Nauk SSSR, 1972, vol. 204, pp. 429-432.

3. Merzhanov, A.G., SHS Process: Combustion Theory and Practice, Arch. Combust., 1981, vol. 1, pp. 23-48.

4. Merzhanov, A.G., Self-Propagating High-Temperature Synthesis: Twenty Years of Search and Findings, in Combustion and Plasma Synthesis of High Temperature Materials, Munir, Z.A. and Holt, J.B., Eds., VCH Publishers, 1990, pp. 1-53.

5. Merzhanov, A.G., Theory and Practice of SHS: Worldwide State of the Art and the Newest Results, Int. J. SHS, 1993, vol. 2, no. 2, pp. 113-158.

6. Borovinskaya, I.P. and Loryan, V.E., Self-Propagating High-Temperature Synthesis of Titanium Nitrides under High Nitrogen Pressures, Poroshk. Metall., 1978, vol. 11, no. 191, pp. 42-45.

7. Borovinskaya, I.P., Combustion Processes and Chemical Synthesis, Arch. Combust., 1974, vol. 5, no. 2, pp. 145-161.

8. Aldushin, A.P., Merzhanov, A.G., and Seplyarskii, B.S., Theory of Filtration Combustion in Metals, Fiz. Goreniya Vzryva, 1976, vol. 12, no. 3, pp. 323-332.

9. Aldushin, A.P., Martem'yanova, T.M., Merzhanov, A.G., Khaikin, B.I., and Shkadinsky, K.G., Autovibrational Propagation of the Combustion Front in Heterogeneous Condensed Media, Fiz. Goreniya Vzryva, 1973, vol. 9, pp. 613-626.

10. Aldushin, A.P., Seplyarskii, B.S., and Shkadinsky, K.G., Theory of Filtrational Combustion, Fiz. Goreniya. Vzryva, 1980, vol. 16, no. 1, pp. 36-45.

11. Mukasyan, A.S., Martynenko, V.M., Merzhanov, A.G., Borovinskaya, I.P., and Blinar, M.Y., Mechanism and Principles of Silicon Combustion in Nitrogen, Fiz. Goreniya Vzryva, 1986, vol. 22, no. 5, pp. 43-49.

12. Munir, Z.A. and Anselmi-Tamburini, U., Self-Propagating Exothermic Reactions: The Synthesis of High Temperature Materials by Combustion, Mater. Sci. Rep., 1989, vol. 3, pp. 277-365.

13. Varma, A., Rogachev, A.S., Mukasyan, A.S., and Hwang, S., Combustion Synthesis of Advanced Materials: Principles and Applications, Adv. Chem. Eng., 1998, vol. 24, pp. 79-225.

14. Merzhanov, A.G., Condensed-Phase Combustion, Russian Academy of Science, 2000. 
15. Frankhouser, W.L., Brendley, K.W., Kieszek, M.C., and Sullivan, S.T., Gasless Combustion Synthesis of Refractory Compounds, Noyes Publications, 1985.

16. McCauley, J.W., A Historical and Technical Perspective on SHS, Ceram. Eng. Sci. Proc., 1990, vol. 119, pp. 1137-1181.

17. Puszynski, J.A., Kinetics and Thermodynamics of SHS Reactions, Int. J. SHS, 2001, vol. 10, no. 3, pp. 265293.

18. Puszynski, J.A. and Hlavacek, V., Synthesis and Processing of Ceramic Materials, Ind. Eng. Chem. Res., 1996, vol. 35, pp. 349-377.

19. Hlavacek, V., Combustion Synthesis of Inorganic Materials (SHS): History and Recent Development, Am. Ceram. Soc. Bull., 1990, vol. 69, no. 3, pp. 240-243.

20. Walton, J.D. and Poulos, N.E., Cermets for Thermite Reactions, J. Am. Ceram. Soc., 1959, vol. 42, no. 1, pp. 40-49.

21. White, W.E. and Bushley, A.H., Aluminum Phosphide, in Inorganic Synthesis, New York: McGraw-Hill, 1953, vol. IV, p. 23.

22. Titterington, R., and Simpson, A.G., The Production and Fabrication of Tantalum Powder, in Symposium on Powder Metallurgy, Special Report no. 58, London (UK): The Iron and Steel Institute, 1956, pp. 11-18.

23. Huffadine, J.B., The Fabrication and Properties of Molybdenum Disilicide and Molybdenum DisilicideAlumina, in Special Ceramics, Popper, P., Ed., New York: Academic Press, 1960, p. 220.

24. Krapf, S., Thermal Reaction Process, Ber. Dtsch. Keram. Ges., 1954, vol. 31, no. 1, p. 18.

25. Stringer, R.K. and Williams, L.S., Reaction Pressing: A New Fabrication Concept for Intermetallic and MetalMetalloid Compounds, in Special Ceramics 4, British Ceramic Research Association, New York: Academic Press, 1967, p. 37.

26. McKenna, P.M., Process for Preparing Tungsten Monocarbide, US Patent 3379503, 1968.

27. Hardt, A.P., and Phung, P.V., Propagation of Gasless Reactions in Solids: Analytical Study of Exothermic Intermetallic Reaction Rates, Combust. Flame, 1973, vol. 21, pp. 77-89.

28. McCauley, J.W., Corbin, N.D., Resetar, T.M., and Wong, P., Simultaneous Preparation and Self-Sintering of Materials in the System Ti-B-C, Ceram. Eng. Sci. Proc., 1982, vol. 3, nos. 9, 10, pp. 538-540.

29. McCauley, J.W., Corbin, N.D., Rochester, N.E., DeMarco, J.J., Schioler, L., and Wong, P., Key Physical Characteristics for Predicting Zr Burning Characteristics, Proc. 29th Power Source Symp., 1981, pp. 19-23.

30. Corbin, N.D. and McCauley, J.W., Self-Propagating High Temperature Synthesis (SHS): Current Status and Future Prospects, MTL MS 86-1, Watertown, MA, May 1986.

31. Corbin, N.D., Resetar, T.M., McCauley, J.W., and Moon, K.A., Energy-less Manufacturing of Advanced Ceramics by SHS, Proc. 1984 Army Sci. Conf., West Point, NY, June 1984, p. 11.

32. Gabriel, K.A., Lin, S.S., McCauley, J.W., Alexander, J.R., Resetar, T.M., and Lowder, L.J., Synthesis and Characterization of Nickel-Doped and Aluminum-
Doped Titanium Carbide, in Materials Processing by Self-Propagating High Temperature Synthesis (SHS), MTL-SP-87-3, 1987, pp. 313-338.

33. Resetar, T.M., and McCauley, J.W., Physical and Chemical Characterization of Soviet-Produced SHS Powder, in Materials Processing by Self-Propagating High Temperature Synthesis (SHS), MTL-SP-87-3, 1987, pp. 339-358.

34. Materials Processing by Self-propagating High Temperature Synthesis, DARPA/Army SHS Symp. Proc. (FL, Daytona Beach, 1985), Gabriel, K.A., Wax, S., and McCauley, J.W., Eds., MTL-SP-87-3, Watertown, MA: U.S. Army Materials Technology Laboratory, 1987, p. 509.

35. McCauley, J.W., Gabriel, K.A., and Resetar, SHS Processing as Reaction Sintering, Ceram. Bull., 1986, vol. 65 , p. 531.

36. Holt, J.B. and Kingman, D.D., Emergent Process Methods for Ceramic Science, Proc. Univ. Conf. on Ceramic Sci., North Carolina State Univ., 1982.

37. Crider, J.F., Self-Propagating High Temperature Synthesis-A Soviet Method for Producing Ceramic Materials, Ceram. Eng. Sci. Proc., 1982, vol. 3, nos. 9, 10, pp. 519-528.

38. Sivashinsky, G.I. and Matkowsky, B.J., Propagation of Pulsating Reaction Front in Solid Fuel Combustion, SIAM J. Appl. Math., 1978, vol. 35, pp. 465-478.

39. Margolis, S.B., Kaper, H.G., Leaf, G.K., and Matkowsky, B.J., Bifurcation of Pulsating and Spinning Reaction Fronts in Condensed Two-Phase Combustion, Combust. Sci. Technol., 1985, vol. 43, pp. 127-165.

40. Bayliss, A., and Matkowsky, B.J., Two Routes to Chaos in Condensed Phase Combustion, SIAM J. Appl. Math., 1990, vol. 50, pp. 437-459.

41. Booty, M.R. and Matkowsky, B.J., Modes of Burning in Filtration Combustion, Eur. J. Appl. Math., 1991, vol. 2, pp. 17-41.

42. Booty, M.R. and Matkowsky, B.J., On the Stability of Counter Flow Combustion, Combust. Sci. Technol., 1991, vol. 80, pp. 231-264.

43. Matkowsky, B.J., and Volpert, V.A., Coupled Nonlocal Complex Ginzburg-Landau Equations in Gasless Combustion, Physica, Ser. D, 1992, vol. 54, pp. 203-219.

44. Shkadinsky, K.G., Shkadinskaya, G.V., Matkowsky, B.J., and Volpert, V.A., Combustion Synthesis of a Porous Layer, Combust. Sci. Technol., 1992, vol. 88, pp. 247270.

45. Shkadinsky, K.G., Shkadinskaya, G.V., Matkowsky, B.J., and Volpert, V.A., Combustion of Porous Samples with Deformation of High Temperature Products, Int. J. SHS, 1992, vol. 1, no. 3, pp. 371-391.

46. Shkadinsky, K.G., Shkadinskaya, G.V., Matkowsky, B.J., and Volpert, V.A., Two-Front Traveling Waves in Filtration Combustion, SIAM J. Appl. Math., 1993, vol. 53, no. 1, pp. 128-140.

47. Matkowsky, B.J. and Volpert, V.A., Spiral Gasless Condensed Phase Combustion, SIAM J. Appl. Math., 1994, vol. 54, no. 1, pp. 132-146.

48. Aldushin, A.P., Matkowsky, B.J., and Volpert, V.A., Interaction of Gasless and Filtration Combustion, Combust. Sci. Technol., 1994, vol. 99, nos. 1-3, pp. 75-103. 
49. Aldushin, A.P., Matkowsky, B.J., Shkadinsky, K.G., Shkadinskaya, G.V., and Volpert, V.A., Combustion of Porous Samples with Melting and Flow of Reactants, Combust. Sci. Technol., 1994, vol. 99, nos. 4-6, pp. 313-343.

50. Aldushin, A.P., Matkowsky, B.J., and Volpert, V.A., Enhancement of Gasless Combustion Synthesis by Counterflow Gas Filtration, Combust. Sci. Technol., 1995, vol. 103, nos. 1-6, pp. 1-20.

51. Aldushin, A.P., Matkowsky, B.J., and Volpert, V.A., Stoichiometric Combustion Waves and Their Stability, Combust. Flame, 1995, vol. 101, nos. 1, 2, pp. 15-25.

52. Raymond, C.S., Bayllis, A., Matkowsky, B.J., and Volpert, V.A., Transitions to Chaos in Condensed Phase Combustion with Reactant Melting, Int J. SHS, 2001, vol. 10, no. 2, pp. 133-150.

53. Volpert, Vit.A., and Volpert, Vl.A., Propagation of Frontal Polymerization-Crystallization Waves, Eur. J. Appl. Math., 1994, vol. 5, pp. 201-215.

54. Goldfelder, P.M., Volpert, V.A., Ilyashenko, V.M., Khan, A., Pojman, J.A., and Solovyov, S.E., Mathematical Modeling of Free Radical Polymerization Fronts, J. Phys. Chem., Ser. B, 1997, vol. 101, pp. 3474-3482.

55. Raymond, C.S., Shkadinsky, K.G., and Volpert, V.A., Gravitational Effects in Liquid Flame Thermite Systems, Comb. Sci. Technol., 1998, vol. 131, nos. 1-6, pp. 107-129.

56. Goldfelder, P.M., and Volpert, V.A., Nonadiabatic Frontal Polymerization, J. Eng. Mathem., 1998, vol. 34, no. 3, pp. 301-318.

57. Spade, C.A. and Volpert, V.A., Mathematical Modeling of Interfacial Gel Polymerization, Math. Computer Modeling, 1999, vol. 30, pp. 67-73.

58. Schult, D.A., and Volpert, V.A., Linear Stability Analysis of Thermal Free Radical Polymerization Waves, Int. J. SHS, 1999, vol. 8, no. 4, pp. 417-440.

59. Pojman, J.A., Masere, J., Petretto, E., Rustici, M., Huh, D.-S., Kim, M.S., and Volpert, V.A., The Effect of Reactor Geometry on Frontal Polymerization Spin Modes, Chaos, 2002, vol. 12, no. 1, pp. 56-65.

60. Perry, M.F. and Volpert, V.A., Linear Stability Analysis of Two Monomer Systems of Frontal Polymerization, Chem. Eng. Sci., 2004, vol. 59, pp. 3451-3460.

61. Devadoss, D.E., Pojman, J.A., and Volpert, V.A., Mathematical Modeling of Thiolene Frontal Polymerization, Chem. Eng. Sci., 2006, vol. 61, pp. 1261-1275.

62. Comissiong, D.M.G., Gross, L.K., and Volpert, V.A., Frontal Polymerization in the Presence of an Inert Material, J. Eng. Math., 2006, vol. 54, pp. 389-402.

63. Comissiong, D.M.G., Gross, L.K., and Volpert, V.A., The Enhancement of Weakly Exothermic Polymerization Fronts, J. Eng. Math., 2007, vol. 57, pp. 423-435.

64. Puszynski, J.A., Degreve, J., Kumar, S., and Hlavacek, V., Propagation of Reaction Fronts in Exothermic Heterogeneous Non-Catalytic Systems Solid-Solid and Solid-Gas, Lect. Appl. Math., 1986, vol. 24, p. 27.

65. Puszynski, J.A. and Hlavacek, V., Front Instability and Fingering Effects in Noncatalytic Exothermic Reactions, Jpn. Chem. Eng. Symp. Ser., 1986, vol. 4, p. 62.

66. Degreve, J., Dimitriou, P., Puszynski, J.A., Hlavacek, V., Valone, S., and Behrens, R., Numerical Res- olution of Front Phenomena by Regridding Techniques, ACS Symp. Ser., 1987, vol. 353, p. 376.

67. Puszynski, J.A., Degreve, J., and Hlavacek, V., Modeling of the Exothermic Solid-Solid Noncatalytic Reactions, Ind. Eng. Chem. Res., 1987, vol. 26, p. 1424.

68. Degreve, J., Dimitriou, P., Puszynski, J.A., Hlavacek, V., Valone, S., and Behrens R., Use of 2D Adaptive Mesh in Simulation of Combustion Front Phenomena, Comput. Chem. Eng., 1987, vol. 11, pp. 749-755.

69. Degreve, J., Dimitriou, P., Puszynski, J.A., Hlavacek, V., Modeling of Strongly Exothermic Reactions on a Supercomputer, Chem. Eng. Comm., 1987, vol. 58, pp. 105-118.

70. Puszynski, J.A., Kumar, S., Dimitriou, P., and Hlavacek, V., A Numerical and Experimental Study of Reaction Front Propagation in Condensed Phase Systems, Z. Naturforsch., Ser. A, 1988, vol. 43, pp. 10171025.

71. Dandekar, H.W., Agrafiotis, C., Puszynski, J.A., and Hlavacek, V., Modeling and Analysis of Filtration Combustion for Synthesis of Transition Metal Nitrides, Chem. Eng. Sci., 1990, vol. 45, p. 2499.

72. Dandekar, H.W., Puszynski, J.A., and Hlavacek, V., A Numerical Study of the Combustion Synthesis of Transition Metal Nitrides, AIChE J., 1990, vol. 36, p. 1651.

73. Dandekar, H., Puszynski, J.A., Degreve, J., and Hlavacek, V., Reaction Front Propagation Characteristics in Non-Catalytic Exothermic Gas-Solid Systems, Chem. Eng. Commun., 1990, vol. 92, p. 199.

74. Dimitriou, P., Puszynski, J.A., and Hlavacek, V., On the Dynamic Equations Describing Gasless Combustion, Combust. Sci. Technol., 1989, vol. 68, pp. 101-111.

75. Kumar, S., Puszynski, J.A., and Hlavacek, V., Combustion Characteristics of Solid-Solid Systems: Experiment and Modeling, in Combustion and Plasma Synthesis of High Temperature Materials, VCH Publishers, 1990, pp. 273-280.

76. Dandekar, H., Puszynski, J.A., and Hlavacek, V., Modeling of Transition Metal Nitridation in Combustion Regime, Materials Sci. Monographs, Ser. B, vol. 66, 1991, p. 1207.

77. Makino, A. and Law, C.K., Heterogeneous Flame Propagation in the Self-Propagating High-Temperature Synthesis (SHS) Process: Theory and Experimental Comparisons, Twenty-Fourth Symposium (International) on Combustion, Pittsburgh: The Combustion Institute, 1992, pp. 1883-1891.

78. Makino, A. and Law, C.K., SHS Combustion Characteristics of Several Ceramics and Intermetallic Compounds, J. Am. Ceram. Soc., 1994, vol. 77, pp. 778-786.

79. Makino, A. and Law, C.K., Burning Velocity of the Heterogeneous Flame Propagation in the SHS Process Expressed in Explicit Form, Combust. Flame, 1995, vol. 101, pp. 551-555.

80. Makino, A. and Law, C.K., Bimodal Particle Dispersion in the Nonadiabatic Heterogeneous SHS Flame Propagation, Combust. Sci. Technol., 1995, vol. 106, pp. 193201.

81. Makino, A. and Law, C.K., Analytical Extinction Criterion for the Non-Adiabatic Heterogeneous SHS Flame Propagation, Int. J. SHS, 1995, vol. 4, no. 1, pp. 5-34. 
82. Makino, A. and Law, C.K., Self-Propagating HighTemperature Synthesis Flammable Range and Dominant Parameters for Synthesizing Several Ceramics and Intermetallic Compounds under Heat Loss Conditions, J. Am. Ceram. Soc., 1996, vol. 79, pp. 3097-3102.

83. Makino, A. and Law, C.K., Pulsating Instability in the Nonadiabatic Heterogeneous SHS Flame: Theory and Experimental Comparisons, Twenty-Sixth Symposium (International) on Combustion, Pittsburgh: The Combustion Institute, 1996, pp. 1867-1874.

84. Makino, A. and Law, C.K., On the Transition Boundary from Steady to Pulsating Combustion in SHS Flame, Twenty-Seventh Symposium (International) on Combustion, Pittsburgh: The Combustion Institute, 1998, pp. 2469-2476.

85. Makino, A. and Law, C.K., Transient Radiative Initiation of the Heterogeneous Flame in SHS: Theory and Experimental Comparisons, Proc. Combust. Inst., 2000, vol. 28, pp. 1439-1446.

86. Makino, A. and Law, C.K., On the Correspondence between the Homogeneous and Heterogeneous Theories of SHS, Combust. Flame, 2001, vol. 124, pp. 268274.

87. Makino, A. and Law, C.K., Extinction Thickness in the SHS Flame Propagation in Two-Layered Composite Medium, Proc. Combust. Inst., 2002, vol. 29, pp. 10931100.

88. He, C. and Stangle, G.C., A Micromechanistic Model of the Combustion Synthesis Process: Mechanism of Ignition, J. Mater. Res., 1998, vol. 13, pp. 146-155.

89. Kanury, A.M., Kinetic Model for Metal and Nonmetal Reactions, Metall. Trans., Ser. A, 1992, vol. pp. 23492356.

90. Bhattacharya, A.K., Temperature-Enthalpy Approach to the Modeling of Self-Propagating Combustion Synthesis of Materials, J. Mater. Sci., 1992, vol. 27, pp. 3050-3061.

91. Varma, A., Cao, G., and Morbidelli, M., Self-Propagating Solid-Solid Non-Catalytic Reactions in Finite Pellets, AIChE J., 1990, vol. 36, no. 7, pp. 1032-1038.

92. Munir, Z.A. and Holt, J.B., The Combustion Synthesis of Refractory Nitrides, Part 1: Theoretical Analysis, J. Mater. Sci., 1987, vol. 22, pp. 710-714.

93. Munir, Z.A., Electrically Stimulated SHS, Int. J. SHS, 1997, vol. 6, no. 20, pp. 165-186.

94. Feng, A. and Munir, Z.A., Field-Assisted Self-Propagating Synthesis of Beta-SiC, J. Appl. Phys., 1994, vol. 7, no. 3, pp. 1927-1928.

95. Kawase, K. and Munir, Z.A., Field-Activated SelfPropagating High-Temperature Synthesis of Iron Aluminides, Int. J. SHS, 1998, vol. 7, no. 1, pp. 95-102.

96. Gedevanishvili, S. and Munir, Z.A., The Influence of Electric Field on the Mechanism of Combustion Synthesis of Tungsten Silicides, J. Mater. Res., 1995, vol. 10, pp. 2642-2647.

97. Anselmi-Tamurini, U., Maglia, F., Spinolo, G., and Munir, Z.A., Nickel/Yttria-Stabilized Zirconia Cermets from Combustion Synthesis: Effect of Process Parameters on Product Microstructure, J. Am. Ceram. Soc., 1998, vol. 81, pp. 1765-1772.
98. Gedevanishvili, S. and Munir, Z.A., The Synthesis Of Tib2-Tial3 Composites by Field-Activated Combustion, Mater. Sci. Eng., Ser. A., 1998, vol. 246, pp. 81-85.

99. Shon, I.J. and Munir, Z.A., Synthesis of TiC and TiC$\mathrm{Cu}$ Composites and $\mathrm{TiC}-\mathrm{Cu}$ Functionally Graded Materials by Electothermal Combustion, J. Am. Ceram. Soc., 1998, vol. 81, pp. 3243-3248.

100. Feng, A., Graeve, O.A., and Munir, Z.A., Modeling Solution for Electric Field-Activated Combustion Synthesis, Comput. Mater. Sci., 1998, vol. 12, pp. 137-155.

101. Feng, A., Orling, T., and Munir, Z.A., Field-Activated Pressure-Assisted Combustion Synthesis of Polycrystalline $\mathrm{Ti}_{3} \mathrm{SiC}_{2}$, J. Mater. Res., 1999, vol. 14, pp. 925939.

102. Orru, R., Cao, G., and Munir, Z.A., Field-Activated Combustion Synthesis of Titanium Aluminides, Metall. Mater. Trans., Ser. A, 1999, vol. 30, pp. 1101-1108.

103. Carillo-Heian, E.M., Graeve, O.A., Feng, A., Faghih, J.A., and Munir, Z.A., Modeling Studies of the Effect of Thermal and Electrical Conductivities and Relative Density on Field-Activated Self-Propagating Combustion Synthesis, J. Mater. Res., 1999, vol. 14, pp. 1949-1958.

104. Dunmead, S.D., Munir, Z.A., and Holt, J.B., Temperature Profile Analysis in Combustion Synthesis: Theory and Background, J. Am. Ceram. Soc., 1992, vol. 75, no. 1, pp. 180-188.

105. Wang, L.L. and Munir, Z.A., Kinetic Analysis of the Combustion Synthesis of Molybdenum and Titanium Silicides, Metall. Trans., Ser. B, 1995, vol. 26, pp. 595601.

106. Lis, J., Majorowski, S., Puszynski, J.A., and Hlavacek, V., Sintering Studies of SIALONs Synthesized by SHS, Proc. Electrochem. Soc.-High Temperature Materials Chemistry, 1990, p. 135.

107. Agrafiotis, C., Lis, J., Puszynski, J.A., and Hlavacek, V., Combustion Synthesis of $\mathrm{Si}_{3} \mathrm{~N}_{4}-\mathrm{SiC}$ Composites, J. Am. Ceram. Soc., 1990, vol. 73, no. 11, p. 3514.

108. Puszynski, J.A., Majorowski, S., Hlavacek, V., and Zdaniewski, W., Magnesiothermic Synthesis of Ultrafine Titanium Diboride, its Reactivity and Retention of Impurities in Consolidated Compacts, Materials Sci. Monographs, Ser. B, vol. 66, 1991, p. 1185.

109. Agrafiotis, C., Puszynski, J.A., and Hlavacek, V., Kinetics of Tantalum and Titanium Nitridation in the Combustion Regime, Combust. Sci. Technol., 1991, vol. 76, p. 187.

110. Lis, J., Majorowski, S., Puszynski, J.A., and Hlavacek, V., Densification of Combustion Synthesized Silicon Nitride, Ceram. Bull., 1991, vol. 70, no. 2, p. 244.

111. Agrafiotis, C.C., Puszynski, J.A., and Hlavacek, V., The Effect of Metal Particle Morphology on the Combustion of Refractory Metals in Nitrogen, J. Am. Ceram. Soc., 1991, vol. 74, p. 2912.

112. Agrafiotis, C.C., Hlavacek, V., and Puszynski, J.A., Direct Synthesis of Composites and Solid Solutions by Combustion Reactions, Combust. Sci. Technol., 1992, vol. 88, p. 187. 
113. Lis, J., Majorowski, S., Puszynski, J.A., and Hlavacek, V., Dense $\beta$ - and $\alpha / \beta$-Sialon Materials by Pressureless Sintering of Combustion Synthesized Powders, Ceram. Bull., 1991, vol. 70, no. 10, p. 1658.

114. Lis, J., Majorowski, S., Hlavacek, V., and Puszynski, J.A., Combustion Synthesis and Densification of $\mathrm{TiB}_{2}-\mathrm{TiC}$ Composite Powders, Int. J. SHS, 1995, vol. 4, no. 3, pp. 275-285.

115. Majorowski, S., Hlavacek, V., and Puszynski, J.A., Ceramic Armor Materials Derived from Combustion Synthesized Powders, Proc. Int. Symp. on Advanced Ceramics and Tribological Applications (Vancouver, BC), The Metallurgical Soc. of CIM, 1995, pp. 581588.

116. Hlavacek, V. and Puszynski, J.A., Combustion Synthesis of Transition Metal Nitrides, in The Chemistry of Transition Metal Carbides and Nitrides, Glasgow: Blackie Academic and Professional, 1996, pp. 233251.

117. Puszynski, J.A., Majorowski, S., and Hlavacek, V., Densification of Aluminum Nitride-Based Ceramic Materials Synthesized by Combustion of Aluminum in Air, Chem. Eng. Commun., 1996, vols. 152-153, pp. 75-85.

118. Puszynski, J.A., Thermochemistry and Kinetics, in Carbide, Nitride, and Boride Materials Synthesis and Processing, Weimer, A.W., Ed., London: Chapman and Hall, 1997, pp. 183-228.

119. Puszynski, J.A. and Miao, S., Chemically-Assisted Combustion Synthesis of Silicon Carbide from Elemental Powders, in Innovative Processes/Syntheses: Ceramics, Glasses, Composites II, Singh, J.P., Ed., Westerville, OH: American Ceramic Soc., 1998, pp. 13-21.

120. Puszynski, J.A. and Miao, S., Kinetic Study of Synthesis of $\mathrm{SiC}$ Powders and Whiskers in the Presence of $\mathrm{KClO}_{3}$ and Teflon, Int. J. SHS, 1999, vol. 8, no. 3, pp. 265-275.

121. Puszynski, J.A., Miao, S., Stefansson, B., and Jagarlamudi, S., In Situ Densification of Combustion Synthesized Coatings, AIChE J., Ser. A, 1997, vol. 43, no. 11, pp. 2751-2759.

122. Liebig, B. and Puszynski, J.A., High Pressure Synthesis of Silicon Nitride-Based Materials with Controlled Morphology and Phase Composition, Int. J. SHS, 1998, vol. 7, no. 1, pp. 34-41.

123. Liebig, B. and Puszynski, J.A., Effect of Combustion Conditions on Synthesis and Sinterability of Silicon Nitride-Based Powders, Ceram. Trans., 2000, vol. 115, pp. 71-83.

124. Puszynski, J.A., Dargar, S.R., and Liebig, B.E., Combustion Synthesis of Ceramic Composites and Solid Solutions from Nanoreactants, Ceram. Trans., 2004, vol. 166, pp. 11-21.

125. Puszynski, J.A., Recent Advances in Synthesis and Densification of Nanomaterials in Self-Propagating High-Temperature Regime, Adv. Sci. Technol., 2006, vol. 45, pp. 994-1003.

126. Dargar, S., Groven, L.J., Swiatkiewicz, J.J., and Puszynski, J.A., In-Situ Densification of SHS Composites from Nanoreactants, Int. J. SHS, 2007, vol. 16, no. 3 , p. 125.
127. Viljoen, H.J. and Lauderback, L.L., Solitons and Nonequilibrium Reactions in Solid Phases, Int. J. SHS, 2000, vol. 9, no. 4, pp. 373-386.

128. Viljoen, H.J. and Hlavacek, V., Solid-Solid Reactions with Mechanical Coupling, Chem. Eng. Sci., 1999, vol. 54, pp. 2985-2990.

129. Viljoen, H.J. and Gordopolov, A., A Study in Mechanochemistry: Pressure-Induced Reactions, Nonequilibrium Phenomena, Int. J. SHS, 2005, vol. 14, no. 3, pp. 387-197.

130. Gordopolov, A., Dzenis, O., and Viljoen, H.J., Compression of Powders in Bridgman Anvil: Fracture and Reaction, Int. J. SHS, 2004, vol. 13, no. 3, pp. 233-243.

131. Richter, C. and Viljoen, H.J., A Combinatorial Approach to Surface Contacts in Solid Phase Reactions, Thermochem. Acta, 2002, vol. 384, pp. 315-328.

132. Stangle, G.C., Venkatachari, K.R., Ostrander, S.P., and Schulze, W.A., Process for Making Ultra-Fine Stabilized Zirconia Particles, US Patent 5716565, 1998.

133. He, C. and Stangle, G.C., A Micromechanistic Model of the Combustion Synthesis Process: Modes of Ignition, J. Mater. Res., 1998, vol. 13, no. 1, pp. 135-145.

134. He, C. and Stangle, G.C., A Micromechanistic Model of the Combustion Synthesis Process: Mechanism of Ignition, J. Mater. Res., 1998, vol. 13, no. 1, pp. 146-155.

135. Stangle, G.C., Venkatachari, K.R., Ostrander, S.P., Schulze, W.A., and Pietras, J.D., Process for Making Ultra-Fine Yttrium-Iron-Garnet Particles, US Patent 5660773, 1997.

136. Stangle, G.C., Venkatachari, K.R., Ostrander, S.P., Schulze, W.A., and Pietras, J.D., Process for Making Ultra-Fine Barium Hexaferrite Particles, US Patent 5660772, 1997.

137. Stangle, G.C., Venkatachari, K.R., Ostrander, S.P., Schulze, W.A., and Pietras, J.D., Process for Making a Sintered Body from Ultra-Fine Superconductive Particles, US Patent 5660774, 1997.

138. Stangle, G.C., Venkatachari, K.R., Ostrander, S.P., and Schulze, W.A., Process for Making Ultra-Fine Barium Titanate Particles, US Patent 5523065, 1996.

139. Jiang, S., Stangle, G.C., Schulze, W.A., and Amarakoon, V.R.W., Synthesis of Yttria-Stabilized Zirconia Nanoparticles by Decomposition of Metal Nitrates Coated on Carbon Powder, J. Mater. Res., 1996, vol. 11, no. 11, pp. 2318-2324.

140. Zhou, Z. and Stangle, G.C., Kinetics of a Non-Catalytic Gas-Solid Chemical Reaction under SHS-Like Conditions, J. Mater. Sci., 1995, vol. 30, no. 12, pp. 32563264.

141. Zhang, Y. and Stangle, G.C., Micromechanistic Model of the Combined Combustion Synthesis-Densification Process, J. Mater. Res., 1995, vol. 10, no. 7, pp. 18281845.

142. Zhang, Y. and Stangle, G.C., Micromechanistic Model of Microstructure Development during the Combustion Synthesis Process, J. Mater. Res., 1995, vol. 10, no. 4, pp. 962-980.

143. Williams, W.C. and Stangle, G.C., Fabrication of NearNet-Shape $\mathrm{Al}_{2} \mathrm{O}_{3}$-Fiber-Reinforced $\mathrm{Ni}_{3} \mathrm{Al}$ Composites by Combustion Synthesis, J. Mater. Res., 1995, vol. 10, no. 7 , pp. 1736-1745. 
144. Venkatachari, K.R., Huang, D., Ostrander, S.P., Schulze, W.A., and Stangle, G.C., A Combustion Synthesis Process for Synthesizing Nanocrystalline Zirconia Powders, J. Mater. Res., 1995, vol. 10, no. 3, pp. 748-755.

145. Venkatachari, K.R., Huang, D., Ostrander, S.P., Schulze, W.A., and Stangle, G.C., Preparation of Nanocrystalline Yttria-Stabilized Zirconia, J. Mater. Res., 1995, vol. 10, no. 3, pp. 756-761.

146. Stangle, G.C., Venkatachari, K.R., Ostrander, S.P., and Schulze, W.A., Process for Making Ultra-Fine Ceramic Particles, US Patent 5468 427, 1995.

147. Huang, D., Venkatachari, K.R., and Stangle, G.C., Influence of Yttria Content on the Preparation of Nanocrystalline Yttria-Doped Zirconia, J. Mater. Res., 1995, vol. 10, no. 3, pp. 762-773.

148. He, C. and Stangle, G.C., The Mechanism and Kinetics of the Niobium-Carbon Reaction under Self-Propagating High-Temperature Synthesis-Like Conditions, J. Mater. Res., 1995, vol. 10, no. 11, pp. 2829-2841.

149. Zhang, Y. and Stangle, G.C., A Micromechanistic Model of the Combustion Synthesis Process. I. Theoretical Development, J. Mater. Res., 1994, vol. 9, no. 10, pp. 2592-2604.

150. Zhang, Y. and Stangle, G.C., A Micromechanistic Model of the Combustion Synthesis Process. II. Numerical Simulation, J. Mater. Res., 1994, vol. 9, no. 10, pp. 2605-2619.

151. Zhang, Y. and Stangle, G.C., Preparation of Fine Multicomponent Oxide Ceramic Powder by a Combustion Synthesis Process, J. Mater. Res., 1994, vol. 9, no. 8, pp. 1997-2004.

152. Stangle, G.C. and Williams, W.C., Combustion Synthesis Process Utilizing an Ignitable Primer which Is Ignited after Application of Pressure, US Patent 5342572 , 1994.

153. Stangle, G.C., Niedzialek, S.E., and Williams, W.C., Combustion Synthesis Process Utilizing an Ignitable Primer which Is Ignited after Application of Pressure, US Patent 5340 533, 1994.

154. Abel, J.S., Stangle, G.C., Schilling, C.H., and Aksay, I.A., Sedimentation in Flocculating Colloidal Suspensions, J. Mater. Res., 1994, vol. 9, no. 2, pp. 451461.

155. Zhang, Y. and Stangle, G.C., Ignition Criteria for SelfPropagating Combustion Synthesis, J. Mater. Res., 1993, vol. 8, no. 7, pp. 1703-1711.

156. Niedzialek, S.E., Stangle, G.C., and Kaieda, Y., Functionally Gradient Materials for Use in Thermal Barrier Coating Applications, Int. J. SHS, 1993, vol. 2, no. 3, pp. 269-280.

157. Niedzialek, S.E., Stangle, G.C., and Kaieda, Y., Combustion-Synthesized Functionally Gradient Refractory Materials, J. Mater. Res., 1993, vol. 8, no. 8, pp. 20262034.

158. Golubjatnikov, K.A., Stangle, G.C., and Spriggs, R.M., Economics of Advanced Self-Propagating High-Temperature Synthesis Materials Fabrication, Am. Ceram. Soc. Bull., 1993, vol. 72, no. 12, pp. 96-102.

159. Ford, R.G. and Stangle, G.C., Compositionally Gradient Materials-Unconventional Composites, in High Temperature Ceramic Matrix Composites (Proc. 6th
European Conf. on Composite Materials), 1993, pp. 795-811.

160. Kudesia, R., Niedzialek, S.E., Stangle, G.C., McCauley, J.W., Spriggs, R.M., and Kaieda, Y., Design and Fabrication of TiC/NiAl Functionally Gradient Materials for Joining Applications, Ceram. Eng. Sci. Proc., 1992, vol. 13, nos. 7, 8, pp. 374-383.

161. Golubjatnikov, K.A., Stangle, G.C., and Spriggs, R.M., Cost Performance Goals for Advanced SHS Materials, Int. J. SHS, 1992, vol. 1, no. 2, pp. 284-293.

162. Baya, S.S., Stangle, G.C., and Snyder, R.L., Synthesis of Superconducting Phases in the Tl-Ba-Ca-Cu-O System, in Proc. AIP Conference: Superconductivity and its Applications, Kao, Y.H., Kaloyeros, A.E., and Kwok, H.S., Eds., New York: American Institute of Physics, 1992, vol. 251, pp. 261-273.

163. Hwang, S., Mukasyan, A.S., and Varma, A., Mechanism of Combustion Wave Propagation in Heterogeneous Reaction Systems, Combust. Flame, 1998, vol. 115, 354-363.

164. Varma, A., Rogachev, A.S, Mukasyan, A.S., and Hwang, S., Complex Behavior of Self-Propagating Reaction Waves in Heterogeneous Media, Proc. Natl. Acad. Sci. USA, 1998, vol. 95, pp. 11053-11058.

165. Mukasyan, A.S., Rogachev, A.S., and Varma, A., Mechanism of Reaction Wave Propagation during Combustion Synthesis of Advanced Materials, Chem. Eng. Sci., 1999, vol. 54, pp. 3357-3367.

166. Mukasyan, A.S., Rogachev, A.S., and Varma, A., Microstructural Mechanisms of Combustion in Heterogeneous Reaction Media, Proc. Combust. Inst., 2000, vol. 28, pp. 1413-1419.

167. Varma, A., Mukasyan, A.S., and Hwang, S., Dynamics of Self-Propagating Reactions in Heterogeneous Media: Experiments and Model, Chem. Eng. Sci., 2001, vol. 56, pp. 1459-1466.

168. Mukasyan, A.S., Pelekh, A, Varma, A., Rogachev, A.S., and Jenkins, A., The Effects of Gravity on Combustion Synthesis in Heterogeneous Gasless Systems, AIAA J., 1997, vol. 35, no. 11, pp. 1821-1828.

169. Lau, C., Mukasyan, A.S., Pelekh, A., and Varma, A., Mechanistic Studies in Combustion Synthesis of NiAl$\mathrm{TiB}_{2}$ Composites: Effects of Gravity, J. Mater. Res., 2001, vol. 16, no. 6, pp. 1614-1625.

170. Lau, C., Mukasyan, A.S., and Varma, A., Materials Synthesis by Reduction-Type Combustion Reaction: Influence of Gravity, Proc. Combust. Inst., 2002, vol. 29, pp. 1101-1108.

171. Lau, C., Mukasyan, A.S., and Varma, A., Reaction and Phase Separation Mechanisms during Synthesis of Alloys by Thermite-Type Combustion Reactions, J. Mater. Res., 2003, vol. 18, no. 1, pp. 121-129.

172. Galstyan, G., Chatilyan, H.A., Kirakosyan, A., Kharatyan, S.L, Mukasyan, A.S., and Varma, A., Reactive Diffusion in Mo-Si System above Melting Point of Silicon, Defects Diffusion Forum, 2005, vols. 237-240, pp. 873-878.

173. Kharatyan, S.L., Chatilyan, H.A., Mukasyan, A.S., Simonetti, D.A., and Varma, A., Influence of Heating Rate on Kinetics of Rapid High-Temperature Reactions in Condensed Heterogeneous Media: Mo-Si System, AIChE J., 2005, vol. 51, no. 1, pp. 261-270. 
174. Thiers, L., Leitenberger, B., Mukasyan, A.S., and Varma, A., Influence of Preheating Rate on Kinetics of High-Temperature Gas-Solid Reactions, AIChE J., 2000, vol. 46, no. 12, pp. 2518-2524.

175. Lebrat, J.P. and Varma, A., Self-Propagating High-Temperature Synthesis of $\mathrm{Ni}_{3} \mathrm{Al}$, Comb. Sci. Technol., 1992, vol. 88, p. 211.

176. Rogachev, A.S., Varma, A., and Merzhanov, A.G., The Mechanism of Self-Propagating High-Temperature Synthesis of Nickel Aluminides, Part I: Formation of the Product Microstructure in a Combustion Wave, Int. J. SHS, 1993, vol. 2, no. 1, pp. 25-38.

177. Rogachev, A.S., Shugayev, V.A., Kachelmyer, C.R., and Varma, A., Mechanism of Structure Formation during Combustion Synthesis of Materials, Chem. Eng. Sci., 1994, vol. 49, no. 24, pp. 4949-4958.

178. Zhou, E., Bhaduri, S., Bhaduri, S.B., Lewis, I.R., and Griffiths, P.R., Auto Ignition Processing of Nanocrystalline Zirconia, in Proc. and Properties of Nanocrystalline Materials, Suryanarayana, C., Singh, J., and Froes, F.H., Eds., Warrendale, PA: TMS, 1995, pp. 123133.

179. Bhaduri, S., Bhaduri, S.B., and Zhou, E., Auto Ignition Processing of Nanocrystalline $\alpha-\mathrm{Al}_{2} \mathrm{O}_{3}$, Nanostr. Mater., 1996, vol. 7, pp. 487-496.

180. Bhaduri, S., Bhaduri, S.B., and Zhou, E., Auto Ignition Synthesis and Consolidation of $\mathrm{Al}_{2} \mathrm{O}_{3}-\mathrm{ZrO}_{2} \mathrm{Nano} / \mathrm{Nano}$ Composite Powders, J. Mater. Res., 1998, vol. 13, pp. 156-166.

181. Bhaduri, S., Bhaduri, S.B., and Zhou, E., Synthesis and Characterization of $\mathrm{CeO}_{2}$-Doped Nanocrystalline $\mathrm{ZrO}_{2}$, Int. J. SHS, 1998, vol. 7, pp. 317-325.

182. Bhaduri, S., Bhaduri, S.B., and Prisbrey, K.A., Auto Ignition Synthesis of Nanocrystalline $\mathrm{MgAl}_{2} \mathrm{O}_{4}$ and Related Nanocomposites, J. Mater. Res., 1999, vol. 14, p. 3571.

183. Mukasyan, A.S., and Dinka, P., Novel Method for Synthesis of Nano-Materials: Combustion of Active Impregnated Layer, J. Adv. Eng. Mater., 2007, vol. 9, pp. 653-657.

184. Lan, A. and Mukasyan, A.S., Perovskite-Based Catalysts for Direct Methanol Fuel Cells, J. Phys. Chem., 2007, vol. 26, pp. 9573-9582.

185. Mukasyan, A.S. and Dinka, P., Novel Approaches to Solution-Combustion Synthesis of Nanomaterials, Int. J. SHS, 2007, vol. 16, no. 1, pp. 23-35.

186. Mukasyan, A.S., Epstein, P., and Dinka, P., SolutionCombustion Synthesis of Nanomaterials, Proc. Combust. Inst., 2007, vol. 31, no. 2, pp. 1789-1795.

187. Dinka, P. and Mukasyan, A., Perovskite Catalysts for the Auto-Reforming of Sulfur Containing Fuels, J. Power Sources, 2007, vol. 167, pp. 472-481.

188. Dinka, P. and Mukasyan, A., In Situ Preparation of the Supported Catalysts by Solution-Combustion Synthesis, J. Phys. Chem., 2005, vol. 109, no. 46, pp. $21627-$ 21633.

189. Yi, H.C. and Moore, J.J., Combustion Synthesis of TiNi Intermetallic Compounds, J. Mater. Sci., 1989, vol. 24, pp. 3449-3455.

190. Moore, J.J., Readey, D.W., Feng, H.J., Monroe, K., and Mishra, B., The Combustion Synthesis of Advanced Materials, J. Metals, 1994, vol. 11, pp. 72-78.
191. Feng, H.J., Moore, J.J., and Wirth, D.G., Combustion Synthesis of Ceramic-Metal Composite Materials: The TiC $-\mathrm{Al}_{2} \mathrm{O}_{3}-\mathrm{Al}$ System, Metall. Trans., Ser. A, 1992, vol. 23, pp. 2373-2379.

192. Ayres, R., Burkes, D., Ottoli, G., Yi, H.C., Guigne, J.Y., and Moore, J.J., The Application of Energetic SHS Reactions in the Synthesis of Multifunctional Bone Tissue Engineering and Drug Delivery Systems, Mater. Res. Symp. Proc., 2006, vol. 896, pp. 1-13.

193. Logan, K.V., Sparrow, J.T., and McLemore, W.J.S., Experimental Modeling of Particle-Particle Interactions during $\mathrm{SHS}$ of $\mathrm{TiB}_{2}-\mathrm{Al}_{2} \mathrm{O}_{3}$, in Combustion and Plasma Synthesis of High-Temperature Materials, VCH Publishers, 1990, pp. 219-228.

194. Keckes, L.J., Kottke, T., and Niiler, A., Powder Purity and Morphology Effects in Combustion Synthesis Reactions, in Combustion and Plasma Synthesis of High-Temperature Materials, VCH Publishers, 1990, pp. 157-162.

195. Niiler, A., Keckes, L.J., and Kottke, T., Shock Consolidation of Combustion-Synthesized Ceramics, in Combustion and Plasma Synthesis of High-Temperature Materials, VCH Publishers, 1990, pp. 309-314.

196. LaSalvia, J., Meyer, L.W., Hoke, D., Niiler, A., and Meyers, M.A., Reaction Synthesis/Dynamic Compaction of Titanium Carbide and Titanium Diboride, in Shock Waves and High-Strain-Rate Phenomena in Materials, Meyers, M.A., Murr, L.E., and Staudhammer, K.P., Eds., New York: Marcel Dekker, 1992, pp. 261-270.

197. Ferreira, A., Meyers, M.A., and Thadhani, N.N., Dynamic Compaction of Titanium Aluminides by Explosively Generated Shock Waves: Microstructure and Mechanical Properties, Metall. Trans., Ser. A, 1992, vol. 23, pp. 3251-3261.

198. Hoke, D.A., Meyers, M.A., Meyer, L.W., and Gray III, G.T., Reaction Synthesis/Dynamic Compaction of Titanium Diboride, Metall. Trans., Ser. A, 1992, vol. 23, pp. 77-86.

199. Meyers, M.A., LaSalvia, J.C., Meyer, L.W., Hoke, D., and Niiler, A., Reaction Synthesis/Dynamic Compaction of Titanium Carbide and Titanium Diboride, J. Phys., Ser. C (Paris), 1991, vol. 3, pp. 123-130.

200. Vecchio, K.S., LaSalvia, J.C., Meyers, M.A., and Gray III, G.T., Microstructural Characterization of SelfPropagating High-Temperature Synthesis: Dynamically Compacted and Hot Pressed Titanium Carbides, Metall. Trans., Ser. A, 1992, vol. 23, pp. 87-97.

201. Meyers, M.A., Olevsky, E.A., Ma, J., and Jamet, J.-M., Combustion Synthesis/Densification of $\mathrm{Al}_{2} \mathrm{O}_{3}-\mathrm{TiB}_{2}$ Composite, Mater. Sci. Eng., 2001, vol. 311, pp. 83-99.

202. Hoke, D.A., Kim, D.K., LaSalvia, J.C., and Meyers, M.A., Combustion Synthesis/Dynamic Compaction of $\mathrm{TiB}_{2}-\mathrm{SiC}$ Composite, J. Am. Ceram. Soc., 1996, vol. 79, pp. 177-182.

203. LaSalvia, J.C., Meyers, M.A., and Kim, D.K., Combustion Synthesis/Dynamic Densification of TiC-Ni Cermets, J. Mater. Synth. Process., 1994, vol. 2, no. 4, pp. 255-274.

204. Hoke, D.A. and Meyers, M.A., Consolidation of Combustion Synthesized Titanium Diboride-Based Materials, J. Am. Ceram. Soc., 1994, vol. 78, no. 2, pp. 275-284. 
205. Kim, D.K., LaSalvia, J.C., Hoke, D.A., and Meyers, M.A., Combustion Synthesis/Dynamic Compaction of $\mathrm{TiB}_{2}-\mathrm{SiC}$ Composite, J. Am. Ceram. Soc., 1995, vol. 78, pp. 275-284.

206. LaSalvia, J.C., Kim, D.K., Lipsett, R.A., and Meyers, M.A., Combustion Synthesis in the Ti-C-Ni-Mo System. I. Macrokinetics and Micromechanisms, Met. Mater. Trans., Ser. A, 1995, vol. 26, pp. 3001-3009.

207. LaSalvia, J.C. and Meyers, M.A., Combustion Synthesis in the Ti-C-Ni-Mo System. II. Analysis, Met. Mater. Trans., Ser. A, 1995, vol. 26, pp. 3011-3019.

208. Raman, R.V., Rele, S.V., Poland, S., LaSalvia, J.C., Meyers, M.A., and Niiler, A.R., The One-Step Synthesis of Dense Titanium-Carbide Tiles, J. Metals, 1995, pp. 23-25.

209. LaSalvia, J.C. and Meyers, M.A., Microstructure, Properties, and Mechanisms of TiC-Mo-Ni Cermets Produced by SHS, Int. J. SHS, 1995, vol. 4, pp. 43-57.

210. Olevsky, E.A., Kristofetz, E.R., and Meyers, M.A., Controlled Net Shape, Density, and Microstructure of TiC-NiTi Cermets Using Quasi-Isostatic Pressing, Int. J. SHS, 1998, vol. 7, pp. 517-528.

211. Strutt, E.R., Olevsky, E.A., and Meyers, M.A., Combustion Synthesis and Quasi-Isostatic Densification of Powder Cermets, Mater. Process. Technol., 2001, pp. 157-166.

212. Work, S.J., Yu, L.H., Thadani, N.N., Meyers, M.A., Graham, R.A., and Hammetter, W.F., Shock-Induced Chemical Synthesis of Intermetallic Compounds, in Combustion and Plasma Synthesis of High-Temperature Materials, VCH Publishers, 1990, pp. 133-143.

213. Ward, R., Thadani, N.N., and Persson, P.A., ShockInduced Reaction Synthesis-Assisted Processing of Ceramics, in Combustion and Plasma Synthesis of High-Temperature Materials, VCH Publishers, 1990, pp. 294-302.

214. Xue, H., Vandersal, K., Carillo-Heian, E., Thadani, N.N., and Munir, Z.A., Initiation of Self-Propagating Combustion Waves in Dense Mo-2Si Reactants through Field Activation, J. Am. Ceram. Soc., 1999, vol. 82, no. 6, pp. 1441-1446.

215. Namjoshi, S.N. and Thadani, N.N., Modeling the Reaction Synthesis of Shock-Densified Ti-Si Powder Mixture Compact, Metall. Trans., Ser. B, 2000, vol. 31, no. 2, pp. 307-316.

216. Vandersal, K.V. and Thadani, N.N., Investigation of Shock-Induced and Shock-Assisted Chemical Reactions in Mo $+2 \mathrm{Si}$ Powder Mixtures, Metall. Trans., Ser. A, 2003, vol. 34, no. 2, pp. 15-23.

217. Vandersal, K.V. and Thadani, N.N., Time-Resolved Measurements of the Shock-Compression Response of Mo + 2Si Elemental Powder Mixtures, J. Appl. Phys., 2003, vol. 94, no. 3, 1575-1583.

218. Martirosyan, K.S. and Luss, D., Carbon Combustion Synthesis of Oxides: Process Demonstration and Features, AIChE J., 2005, vol. 51, no. 10, pp. 2801-2810.
219. Martirosyan, K.S. and Luss, D., Carbon Combustion Synthesis of Ferrites: Synthesis and Characterization, Ind. Eng. Chem. Res., 2007, vol. 46, pp. 1492-1499.

220. Martirosyan, K.S., Iliev, M., and Luss, D., Carbon Combustion Synthesis of Nanostructured Perovskites, Int. J. SHS, 2007, vol. 16, no. 1, pp. 36-45.

221. Martirosyan, K.S., Chang, L., Rantschler, J., Khizroev, S., Luss, D., and Litvinov, D., Carbon Combustion Synthesis and Magnetic Properties of Cobalt Ferrite Nanoparticles, IEEE Trans. Magnetics, 2007, vol. 43, no. 6, pp. 3118-3120.

222. Nersesyan, M.D., Claycomb, J.R., Ritchie, J.T., Miller, J.H., Jr., and Luss, D., Magnetic Fields Produced by Combustion of Metals in Oxygen, Combust. Sci. Technol., 2001, vol. 169, pp. 89-106.

223. Nersesyan, M.D., Ritchie, J.T., Filimonov, I.A., Richardson, J.T., and Luss, D., Electric Field Produced by High Temperature Metal Oxidation, J. Electrochem. Soc., 2002, vol. 149, pp. J11-J17.

224. Martirosyan, K.S., Filimonov, I.A., and Luss, D., New Measuring Techniques of Electric Field Generated by Combustion Synthesis, Int. J. SHS, 2002, vol. 11, pp. 325-333.

225. Martirosyan, K.S., Claycomb, J.R., Gogoshin, G., Yarbrough, R.A., Miller, J.H., Jr., and Luss, D., Spontaneous Magnetization Generated by Spin, Pulsating and Planar Combustion Synthesis, J. Appl. Phys., 2003, vol. 93, pp. 9329-9335.

226. Martirosyan, K.S., Claycomb, J.R., Miller, J.H., Jr., and Luss, D., Generation of the Transient Electrical and Spontaneous Magnetic Fields by Solid State Combustion, J. Appl. Phys., 2004, vol. 96, pp. 4632-4636.

227. Setoodeh, M., Martirosyan, K.S., and Luss, D., Electrical Pulse Formation during High Temperature Reaction between $\mathrm{Ni}$ and Al, J. Appl. Phys., 2006, vol. 99, pp. 084901-1-084901-7.

228. Martirosyan, K.S., Nawarathna, D., Claycomb, J.R., Miller, J.H., Jr., and Luss, D., Complex Dielectric Behavior during the Formation of $\mathrm{BaTiO}_{3}$ by Combustion Synthesis, J. Phys., Ser. D: Appl. Phys., 2006, vol. 39, pp. 3689-3694.

229. Reiss, M.E., Esber, C.M., Van Heerden, D., Gavens, A.J., Williams, M.E., and Weihs, T.P., Self-Propagating Formation Reactions in Nb/Si Multilayers, Mater. Sci. Eng., Ser. A, 1999, vol. 261, pp. 217-222.

230. Gavens, A.J., Van Heerden, D., Mann, A.B., Reiss, M.E., and Weihs, T.P., Effect of Intermixing on Self-Propagating Exothermic Reactions in Al/Ni Nanolaminate Foils, J. Appl. Phys., 2000, vol. 87, no. 3, pp. 1255-1263.

231. Blobaum, K.J., Van Heerden, D., Gavens, A.J., and Weihs, T.P., Al/Ni Formation Reactions: Characterization of the Metastable $\mathrm{Al}_{9} \mathrm{Ni}_{2}$ Phase and Analysis of its Formation, Acta Mater., 2003, vol. 51, no. 13, pp. 38713884. 